\title{
ACHEGAMENTO AO PERFIL LINGÜÍSTICO DOS AUTORES DOS INICIOS DA IDADE CONTEMPORÁNEA
}

Rosario Álvarez

Instituto da Lingua Galega,

Universidade de Santiago de Compostela 



\section{INTRODUCIÓN}

O estudo da variación lingüística, sempre xustificada e nunca exenta de interese, ten especial importancia neste monllo de textos recollidos en Papés ${ }^{1}$, porque se producen nun momento crucial para a historia da lingua galega, nunhas décadas en que se está reinventando a súa escrita, e eles fornecen información fundamental para cońecermos o seu estado pouco antes de que comezase a conformarse paseniñamente o modelo de galego culto contemporáneo. A análise desa variación é igualmente importante para o estudo da gramática, baseado no mellor cońecemento das variantes en liza e dos procesos de cambio lingüístico que se estaban a dar no intre ou que se deron de entón a agora; posto que na súa maior parte estes textos simulan nacer na lingua espontánea do pobo, obviamente galegófono, eles son o retrato máis fiel que poderiamos agardar. Pero, sobre todo, na ocasión deste volume colectivo, interésanos estudar a variación lingüística como un modo de afondar máis no cońecemento interno dos textos contidos en Papés, en gran parte anónimos, co norte de establecer similitudes e diferenzas entre deles, e en definitiva dar trazado un perfil dos posibles autores.

A variación existe dentro dun mesmo autor e tamén dentro dunha mesma obra. De ningún deles se pode afirmar que pretenda ser reflexo "fiel" dunha variedade diatópica determinada (como procurará máis adiante Antonio Fernández Morales, con outras motivacións), nin sequera naquelas obras en que hai

\footnotetext{
${ }^{1}$ Mariño Paz, Ramón / X. R. Barreiro Fernández / Rosa Aneiros Díaz (eds.) (2008): Papés d'emprenta condenada. A escrita galega entre 1797 e 1846 (I). Santiago de Compostela: Consello da Cultura Galega. As referencias aos textos seguen o mesmo sistema de abreviaturas empregado nese volume e no presente, coas seguintes adaptacións particulares: (a) distinguimos entre OPG(GF)-37 (O pleiteante, Gómez del Ferrol) e OPG(RV)-37 (O litigante, Varela Vahamonde); (b) cando nos queremos referir indistintamente a dúas ou máis obras do mesmo título e ano, omitimos o cardinal (p. ex., DE-07 acolle tanto a DE1 coma a DE2).
} 
un maior coidado e éxito en reflectir da maneira máis verosímil a lingua dos paisanos que interveñen; nesta liña, chamamos a atención sobre a necesidade de ter sempre presente que os autores son todos persoas instruídas, con alto nivel cultural, que imitan os rexistros coloquiais populares. Os textos — tanto os máis formais coma os máis coloquiais - mostran polo xeral unha mestura de trazos de variedades lingüísticas diferentes, entrelazados polo autor á súa conveniencia, seleccionados nun abano máis ou menos amplo, consonte a magnitude e seguridade dos seus cońecementos. Así, por exemplo, no estilo "elevado" do soneto de Pardo de Andrade (MPA1-97) atopamos man e mañán xunto a aquil, que pertencen agora e con certeza entón a áreas dialectais diferentes, xunto cun non casual aire "italianizante" que lle outorga ao texto o uso reiterado de $<\mathrm{i}>$ (prep. $d i$, mais tamén istaba, discubrinlle...), ao que se cadra non son alleos semper e come. $\mathrm{O}$ mesmo podemos atopar en obras de estilo popular: se ben na representación dos veciños de Pontedeva (RVP-05, anónimo) non hai ningún trazo que non sexa esperable nun paisano do lugar, en PG-10 Fernández Neira toma posición explícita fronte á variación, acollendo á mantenta formas variantes e excluíndo as que lle parece que non se entenderán (suma, resta, selecciona..., e isto nalgunha medida, sen declaralo, poden facelo todos).

Neste marco introdutorio cómpre lembrar tamén que todos temos unha historia lingüística persoal e que ao longo do noso percurso biográfico imos modificando o acervo orixinario, incorporando uns materiais lingüísticos e perdendo ou abandonando outros. Por iso, para nos achegarmos ben a estes textos, precisamos saber máis destes autores, da súa historia persoal. Non abonda con dicir que Turnes ou Fandiño son santiagueses: ¿de onde procedían realmente?, ¿onde estaban as súas conexións familiares?, ¿cara a onde tomaban cando ían á aldea?... (iso sen contar con que algúns trazos poden ser incorporados dun amigo, do zapateiro, da leiteira, doutro autor...). Igualmente, hai que ter en conta as relacións interpersoais establecidas entre os distintos escritores, en ocasións fondas e estreitas por afinidades culturais e políticas, e mailos axentes das reducidas canles de publicación; todo iso permite supoñer que algúns dos trazos definitorios do galego empregado pasasen duns a outros e que non todo sexa atribuíble á variedade orixinaria de cada un dos protagonistas.

Da análise fina dalgúns textos podemos extraer un perfil verosímil do autor. Por exemplo, o redactor de "Carta recomendada" (CR-12), que asina como 
Ramón González Senra (tense por pseudónimo), di que non sabe "falar con retrónicas" e que non ten a instrución dos xesuítas, pero percíbese que é unha persoa culta (libertade, Faraós), con posibles lecturas en portugués (-ade, sofrir, alfenetes, obrigazon, freguesía, órden..., se callar o futuro de subxuntivo...); para dar un aire de autenticidade paisana e así probar a carencia de retrónicas, inserta expresións populares e disfraza os cultismos botando man dalgunha que outra variante "popular" (jasuita, sigalos, anamigo, adeministrador); semella santiagués, da contorna leste (maos, jues/justicia, uns bes...), e de feito asina en Combarro (O Castiñeiriño). Analizando a lingua do texto, foi cuestionado que as siglas JMP que figuran en RM-44 respondesen ao nome de Juan Manuel Pintos Villar (Xove 1999: 733), a pesar do ben acaídas que viñan, o que enganou non poucos estudosos; agora, grazas a Xosé Ramón Barreiro (Papés: 489), sábese con certeza que o autor é Ramón Malvárez, párroco de Miñortos (Noia), e efectivamente as características canxan co que se espera dun noiés. Noutro lugar, tras analizar a lingua da Parola Poléteca (APP-22), concluïamos que o autor debía ser unha persoa con fortes conexións e trato fluído no círculo dos liberais composteláns que escriben e editan en galego, pero que non se podía identificar con ningún dos escritores desas décadas cońecidos ata hoxe; concluïamos tamén que estabamos diante dun anónimo diferente e que debía proceder dun lugar ao sur de Santiago, dentro do cadrante suroccidental (non tudense, non da beiramar), entre o bloque occidental e o central (Deza, Terra de Montes...) (Álvarez/Montederramo 2006).

Ata agora, falamos de extraer as características dun autor ou dun texto, e tamén de excluír que dous textos sexan do mesmo autor. É moito máis difícil afirmar que un texto é dun autor cońecido, ou que dous ou máis textos son do mesmo autor anónimo, pero non cremos que sexa imposible propor emparellamentos: depende da cantidade de datos que poidamos procesar, cuantificar, cruzar...; desde logo, non abonda con atopar a similitude a través dun trazo (p. ex. o uso dun adxectivo infrecuente, como testo, da grafía $\left\langle\mathrm{x}^{\wedge}>\right.$ ou da evidencia da gheada), nin sequera dun grupo pequeno de trazos.

Esta contribución descritiva da variación lingüística oriéntase a establecer perfís que apoien ou desboten a atribución de autorías. Non somos os primeiros en percorrer ese camińo (Carvalho Calero, Ramón Mariño...), tampouco é a primeira vez que nos botamos a el. Vallan os problemas levantados nos parágrafos anteriores — só unha mostra dos posibles atrancos - como unha advertencia da moita cau- 
tela con que hai que proceder neste asunto da identificación por medio de trazos lingüísticos, mais tamén como declaración de que a dificultade non nos detén. Fronte a outros estudos previos, imos prescindir da análise de trazos gráficos, que se asumen e abandonan, que se copian ou adaptan, que incluso poden ser asunto do editor ou do linotipista, e que ademais pouco teñen que ver coa variación da lingua; non se entenda como un intento de lles restar valor, que o teñen e moito, senón como explicación de que non serven ao noso propósito presente.

O contexto e a ocasión obrígannos a facer unha selección severa dos trazos lingüísticos estudados. Deixamos fóra da nosa análise os trazos léxicos, porque as palabras son moi viaxeiras e no estado actual de cońecemento resultaría imposible establecer con marxe de seguridade abonda cal é o inventario de formas léxicas pertencente ao acervo da variedade orixinaria dun autor e cal o proveniente da adquisición lingüística persoal. Imos centrar a nosa atención nunha selección de trazos morfolóxicos: a forma do adverbio non ante verbo comezado por vogal ( $\$$ 2.1), a forma do mesmo adverbio en combinatoria co clítico acusativo e, secundariamente, con outros clíticos $(\$ 2.2)$; a marca de número no clítico dativo de $3 \mathrm{P}$ plural ( $\$ 3.1$ ) e a variación formal na amálgama 'lles + acusativo 3P’ (\$ 3.2); as formas pronominais empregadas como cuantificador existencial negativo 'ningunha persoa' (\$4); a variación entre nós e nosoutros e entre vós e vosoutros, estas como P5 ( $\$ 5.1)$ ou como P2 (cortesía), fronte a vostede (\$ 5.2); e a opción por formas da serie en -ó ou polas da serie en -á dos adverbios deícticos ( $\$ 6)$. Como se pode apreciar, algúns son trazos pouco estudados en traballos anteriores; todos teñen en común que o uso non debeu estar mediatizado por unha excesiva atención sobre eles: noutras palabras, a falta de reflexión diante da escolla fai que sexan mellores indicios da variedade espontánea dos autores.

\section{2. $N O N, N, N O-$}

\subsection{O adverbio non en posición anteverbal}

Tradicionalmente, na lingua oral espontánea, o adverbio de negación non en posición anteverbal pode adoptar variantes formais condicionadas polas características fónicas do segmento inicial do verbo que segue: mantén a forma plena ante consoante $\{$ non $\}$, pero ante vogal pode tomar unha forma reducida, de modo 
que a variación nestoutra posición é $\{n, n o, n o n\}$. Repárese nestes tres exemplos, tomados do noso corpus, en que o adverbio precede ao verbo hai:

CR-12: ¿Porque non hay justicia nesta terra? (113).

JMP3-45: ¿Que importa a lei humana ni a divina contra esa plaga que a probeza aumenta si ja no hai fe de Cristo na doutrina, si todo está no mundo ja de veta? (123).

ABF1-12: O casarse quér cariño, e se no-o hay sale mal, que n-hai ningun animal indómeto a-o aloumińo (512).

Esta alomorfía do adverbio é un trazo tradicional de moi ampla difusión territorial $^{2}$, mais paso a paso vai esmorecendo na lingua falada e nas últimas décadas case desapareceu da escrita. Non era así en épocas anteriores, e tampouco nas primeiras décadas do século XIX.

No corpus, a maior parte das atestacións son da variante non, que, como dixemos, alterna coas reducidas no mesmo contexto ${ }^{3}$; dito doutro xeito, a presenza de non ante vogal pódese deber a que nesa variedade só existe esa opción ou a que, habendo alomorfía, o usuario escolle esa variante dentro do abano formal que ten ao seu dispor. A nosa análise céntrase nas obras e autores que atestan as formas $n$ - e no, mais ten en conta tamén a concorrencia da forma plena en posición antevocálica para podermos valorar a incidencia nelas (Táboa 1). Mantemos a orde cronolóxica, guiada polo primeiro rexistro de cada autor, para facilitar a comprobación de que non existe unha progresión constante na definición do modelo. Contabilizamos por separado as ocorrencias ante vogal tónica e vogal átona, porque este cambio no contexto prosódico pode condicionar resultados distintos. Nas columnas da dereita facemos un cómputo por autores diferenciados, nas tres posicións, que nos permite ter uns índices de uso e agrupalos por tendencias (de

\footnotetext{
2 Vallan como mostras da ampla difusión xeolectal os seguintes exemplos, tomados de falantes espontáneos: "no-hai madeira ningunha" (Ferreirós de Valboa-Becerreá, LU), "no-era coma agora" (Cela-Bueu, PO), "o resto, pois nu-hai que facerlle" (Saldanxe-A Pastoriza, LU), "no-hai eses traballos" (Ventosela-Ribadavia, OU), "no-está" (Espiñaredo-As Pontes de García Rodríguez, CO), "n-había" (Castro-Boiro, CO; Lubián, ZA; Brués-Boborás, OU).

${ }^{3}$ De forma excepcional, atopamos tamén 3 rexistros ante verbo comezado por consoante ( $2 s-, 1 t$-): "Outro tińa moitas fillas, estas no as quer ó Rey, no sirven p[ar]a andar polo mundo carrexando odres" (PC-36: 479); "pois un ou otro no son os frades" (PC-36: 756); "Ponlles a mau pola igresia o crego, mais anque e bo, no ten efecto a mencińa, cando o remedio e o varon" (MPA2-13: 416).
} 
maior a menor frecuencia das formas reducidas): os do Grupo I non presentan a forma plena; os do Grupo II teñen maioría significativa de formas reducidas; os do Grupo III ofrecen equilibro; os do Grupo IV mostran ampla maioría da forma plena; o Grupo V, formado por aqueles que non presentan formas reducidas, non está presente na táboa.

\begin{tabular}{|c|c|c|c|c|c|c|c|c|}
\hline & \multicolumn{3}{|c|}{ ANTE VOGAL TÓNICA } & \multicolumn{3}{|c|}{ ANTE VOGAL ÁTONA } & \multirow{2}{*}{ TotaIs } & \multirow{2}{*}{ Tendencia } \\
\hline & $n$ & no & non & $n$ & no & non & & \\
\hline DE1-07 & 1 & 1 & 5 & & & 4 & \multirow{2}{*}{$3 / 1 / 17$} & \multirow{2}{*}{ IV } \\
\hline DE2-07 & 2 & & 4 & & & 4 & & \\
\hline LSSA-08 & & 1 & & & 1 & & $0 / 2 / 0$ & I \\
\hline $\mathrm{ABF} 1-12$ & 9 & & 4 & 3 & & 1 & \multirow{4}{*}{$12 / 0 / 8$} & \multirow{4}{*}{ II } \\
\hline ABF2-12 & & & & & & 1 & & \\
\hline ABF4-14 & & & 1 & & & & & \\
\hline ABF7-20 & & & & & & 1 & & \\
\hline MPA2-13 & & 1 & 6 & & & 4 & \multirow{4}{*}{$0 / 3 / 15$} & \multirow{4}{*}{ IV } \\
\hline MPA4-14 & & & 1 & & & & & \\
\hline MPA5-14 & & 2 & & & & & & \\
\hline MPA6-20 & & & 4 & & & & & \\
\hline APP-22 & & & & & 1 & 1 & $0 / 1 / 1$ & III \\
\hline PBS-23 & 5 & & 3 & 6 & & & $11 / 0 / 3$ & II \\
\hline PC-36 & & 3 & 28 & & & 12 & $0 / 3 / 40$ & IV \\
\hline OPG[RV]-37 & & & & 1 & & 1 & $1 / 0 / 1$ & III \\
\hline OPG[GF]-37 & & 1 & 2 & & & 1 & $0 / 1 / 3$ & IV \\
\hline FP1-38 & 1 & & 5 & 1 & & & \multirow{3}{*}{$4 / 0 / 8$} & \multirow{3}{*}{ IV } \\
\hline FP2-sd & & & 1 & & & & & \\
\hline FP3-sd & 2 & & & & & 2 & & \\
\hline OSP1-40 & & 2 & 1 & & & & $0 / 2 / 1$ & III \\
\hline C1836-43 & 1 & & 3 & 1 & & 1 & $2 / 0 / 4$ & IV \\
\hline JMP1-43 & 1 & & 2 & 1 & & & \multirow{3}{*}{$2 / 4 / 5$} & \multirow{3}{*}{ III } \\
\hline JMP3-45 & & 2 & & & 2 & 1 & & \\
\hline JMP4-46 & & & 2 & & & & & \\
\hline RM-44 & 3 & & & & & & $3 / 0 / 0$ & I \\
\hline CCX-46 & 2 & & 3 & 1 & & & $3 / 0 / 3$ & III \\
\hline
\end{tabular}

Táboa 1. Variantes $\{n, n o, n o n\}$ ante vogal inicial do verbo 
Á vista dos datos reproducidos na Táboa 1, podemos tirar como primeira conclusión que, de maneira xeneralizada, as variantes reducidas alternan coas plenas nos mesmos textos; así fan tódolos autores, salvo o anónimo de Labrador (LSSA08) e Ramón Malvárez (RM-44), que integran o moi exiguo Grupo I, pero o número de rexistros é nestes tan baixo que non invalida a conclusión xeral. Obsérvese que non sucede o mesmo á inversa, pois a forma plena reina en exclusiva en tódolos autores e obras que pertencen ao nutrido Grupo V (fóra da táboa), integrado por algo máis da metade das obras, con presenzas moi significativas: OAS-01? (4/0) [ante vogal tónica/ante vogal átona], Arias Teixeiro (1805, 0/1), Fernández Neira (1810, 6/11), AC-12 (1/0), CR-12 (10/3), CFRA-13 (5/5), AC-13 (0/3), CCBM-13 (2/0), DDF-20 (2/2), TQ-20 (7/5 e 6/3), N. P. Díaz (1826, $1 / 1 ; 1828,1 / 1)$, DAS-36 (2/1, $1 / 0$ e 2/2), DGM-36 (7/0), TP-36 (6/3 e 2/4), CPCh-37 (0/5), Añón (1842, 0/1), Turnes (1842, 4/1; 1843, 0/1; 1845, 5/1), Montero Telinge (1844, 1/1), Valladares $(1844,0 / 1 ; 1845,0 / 1)^{4}$ e Camino $(1845,1 / 1 ; 1846,3 / 0)$.

$\mathrm{Na}$ alternancia, as formas plenas son adoito máis frecuentes cás reducidas, de aí que o Grupo IV sexa o máis numeroso da táboa. Só invirten claramente esa relación Fandiño e Boado (Grupo II). Fano tamén en moi menor medida Pintos e Fernández Magariños, nunha situación case de igualdade, polo que preferimos agrupalos cos que mostran igual frecuencia (Varela Vahamonde, en OPG[RV]-37, e mailos anónimos de APP-22 e CCX-46, Grupo III).

En xeral, escóllese ou $n$ - ou no-. Son excepcionais os autores que alternan ambas: o anónimo de DE-07, que mostra unha lixeira preferencia por $n$-, e Pintos, que o fai por no-. As escollas máis decididas, avaladas polo maior número de rexistros, son da variante máis reducida, pola que optan Fandińo, Boado, Varela, Pol e o anónimo de Cambados (C1836-43). Escollen no- Pardo de Andrade, Fernández Magariños, Gómez del Ferrol e os anónimos de LSSA-08, APP-22 e PC-36.

\footnotetext{
${ }^{4}$ Claro que ningún dos exemplos se somete ao contexto da regra enunciada polo autor na súa gramática: "Pois non inoras, se cantas, o que escoitarte m'agrada" (MV1-44, 30), "Parolas jai! d' amor ja non escoito longe do val mimoso en que nacin" (MV2-45, 3). Tras indicar que "este adverbio se apostrofa lo mismo que el en preposición", pasa a describir os casos en que se debe apostrofar ou non. Os que agora nos ocupan son os seguintes: "Debe elidirse y apostrofarse la primera $n$ siempre que a este adverbio sigan [...] la $2^{\text {a }}$ ó $3^{\text {a }}$ persona de singular del presente de indicativo del verbo ser, cualquiera de las de pasado imperfecto, también de indicativo y ante todas las de los diferentes tiempos del verbo estar" (1970: 106). Dito doutro xeito, só ante as formas do verbo estar e ante as de ser que comezan por vogal.
} 
Non semella que haxa unha distribución dialectal estrita entre ambas, senón máis ben unha opción ou práctica individual de cada un, oral e escrita; por iso, este trazo pode ser de grande axuda na identificación dos autores 5 .

Chama a atención a escasa presenza da forma reducida nos diálogos composteláns, sendo que está ben testemuñado no galego occidental e presente aínda hoxe no galego desta comarca ${ }^{6}$ : é minoritario en DE-07 e en PC-36, pero falta por completo en CFRA-13 (asinado por F.R.A.), CCBM-13 (asinado por R.F.), DDF-20, TQ-20, DAS-36 e TP-36. Naturalmente, non se trata de que na altura non existise esa variación na fala compostelá, senón de que o autor ou autores anónimos deses textos, pola razón que fose, non a consideraron entre os trazos populares que trasladaron á escrita. Salientamos tamén que $n$-é forma única en RM-44 (3r), mais falta por completo en CPCh-37 (non, 5r), para o que se postula a mesma autoría de Ramón Malvárez (Papés: 401); tampouco se compadece a práctica do autor anónimo dos diálogos dos esterqueiros (DE-07) coa seguida por Antonio Benito Fandiño, que ao parecer tira a copia, nin coa de Freire Castrillón — desde que sexa el o redactor de AC-13 (non, 3r)—, ambos aludidos como posibles autores (Papés: 27).

\subsection{O adverbio non en combinatoria con clíticos}

1. O adverbio non combina coas variantes diatópicas do pronome acusativo de 3P, con distintos resultados territoriais, a maior parte amalgamados: masc. sg. $\{$ no, noo, nol, nono, nonol, nonno, nonho, non lo\} / fem. sg. \{noa, noal, nona, nonal, nonna, nonha, non la\} (Álvarez 1998: 104-108). O Mapa 1 presenta de xeito moi simplificado a extensión das variantes reducidas no e noa $n a^{7}$, delimitando a área en que é máis constante (grosso modo, as dioceses de Santiago e Mondoñedo; ao sur e leste desa liña hai rexistros esporádicos, con certa concentración nalgunhas

\footnotetext{
5 Temos presente que a grafía extensa pode representar unha pronuncia reducida e enmascarar a realidade morfolóxica; por contra, non é previsible que unha grafía reducida represente unha pronuncia máis extensa.

${ }^{6}$ Dubert (1999: 224), no seu estudo xeolingüístico do concello de Santiago de Compostela, con datos de fins do séc. XX, confirma que ante verbo comezado por vogal existen os alomorfos no e non, e que o primeiro é máis frecuente.

7 O fenómeno está testemuñado xa na Idade Media. Entre os poetas medievais que usan a amálgama está o clérigo santiagués Airas Nunez (Álvarez 1994).
} 
rexións, mais sen formar áreas tan compactas coma a que delimitamos ao norte e oeste. Coma no contexto non + verbo, todo indica que estas formas reducidas están perdendo vitalidade na lingua oral espontánea, substituídas polas tamén tradicionais non o e non a [nono, nona] —que coexisten en toda a área- e, mesmo, polas emerxentes non o e non a [nojo, nona]; a fronteira recúa cara ao occidente, deixando pegadas no leste e no sur, e asemade a área "no, noa" fragméntase internamente.

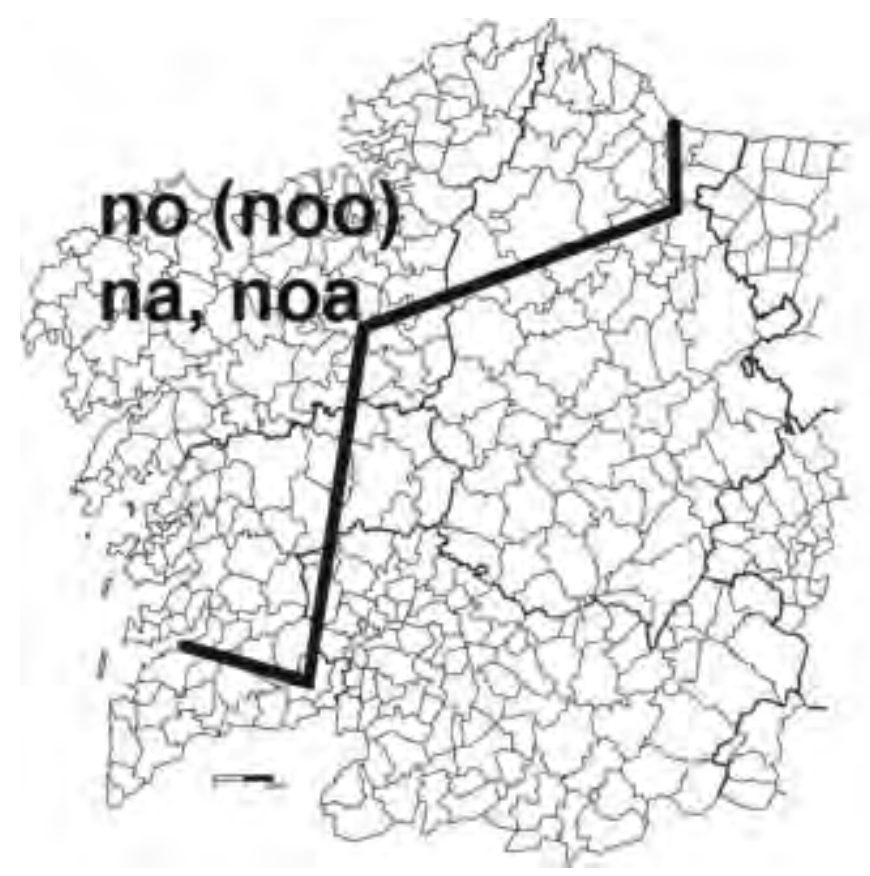

Mapa 1: Área de maior presenza da amálgama no e noa na (adv. non e pron. acusativo 3P) Fonte: Álvarez 1998

Estas variantes están tamén presentes na colectánea reunida en Papés. As grafías poden variar, pero debemos convir en que <non o, non-o, nono, no no, no-no, no'no $>$ representan a secuencia [nono]; as grafías seguras das formas reducidas son <no o, no ó, no-o, n’o, no $>$ e $<$ no a, no à, noa, na, n-a, n’a, n’>. A análise realizada, que exporemos a seguir, segue a pauta descrita anteriormente para o contexto non + verbo; coma entón, centrarémonos nos autores e obras que presentan grafías de amálgamas reducidas. 


\begin{tabular}{|c|c|c|c|c|c|c|c|c|c|c|}
\hline & \multicolumn{4}{|c|}{ Pron. $O(S)$} & \multicolumn{4}{|c|}{ Pron. $A(S)$} & \multirow{2}{*}{$\begin{array}{c}\text { TotAIS } \\
\text { (REDUCIDA/ } \\
\text { PLENA) }\end{array}$} & \multirow{2}{*}{ Tendencia } \\
\hline & $n$ & no & non- & non & $n$ & no & non- & non & & \\
\hline PG-10 & 1 & & 5 & & & & 1 & & $1 / 6$ & IV \\
\hline ABF1-12 & & 3 & 2 & 1 & & & & 2 & $3 / 3$ & III \\
\hline CFRA-13 & 1 & & 1 & & & & 2 & & $1 / 2$ & IV \\
\hline DDF-20 & 2 & & & & & & & & $2 / 0$ & I \\
\hline TQ2-20 & & & 2 & & & 2 & & & $2 / 2$ & III \\
\hline PBS-23 & & & 8 & & 1 & & 2 & & $1 / 10$ & IV \\
\hline PC-36 & 5 & 2 & 5 & & & 2 & & & $9 / 5$ & II \\
\hline CPCh-37 & & & 3 & & 1 & & & & $1 / 3$ & IV \\
\hline FP1-sd & 1 & & 1 & & 1 & & & & \multirow{2}{*}{$3 / 1$} & \multirow{2}{*}{ II } \\
\hline FP3-sd & & & & & 1 & & & & & \\
\hline OSP1-40 & 1 & & & & 3 & & & & $4 / 0$ & I \\
\hline VT3-42 & & & & & 1 & & & & \multirow{2}{*}{$1 / 1$} & \multirow{2}{*}{ III } \\
\hline VT7-46 & & & & & & & 1 & & & \\
\hline JMP2-45 & & & & 3 & & 1 & & & $1 / 3$ & IV \\
\hline CCX-46 & & & 1 & & 1 & & & & $1 / 1$ & III \\
\hline RVV-sd & 2 & & & & & & & & $2 / 0$ & I \\
\hline
\end{tabular}

Táboa 2. Presenza relativa de $\{$ no, nono $\}$ (con fem. e pl.)

2. En liñas xerais, a situación é similar á descrita na alínea anterior (\$2.1). A forma reducida alterna coa grafada como plena nun mesmo texto, e de feito son moi poucos os autores que sempre empregan as primeiras (Grupo I): o anónimo de DDF-20, Fernández Magarińos (OSP1-40) e Varela Vaamonde (RVV-sd) ${ }^{8}$; a eles únense os poucos que as usan de forma preferente (Grupo II), só o anónimo de Cacheiras (PC-36) e Florencio Pol. Os demais móvense entre o equilibro entre ámbalas opcións (Grupo III: Fandiño, Turnes e mailos anónimos da Quintana [TQ2-20] e Xallas [CCX-46]) e a preferencia pola forma plena (Grupo IV: Fernández Neira, Boado, Pintos e os autores anónimos de CFRA-13 e CPCh-37).

\footnotetext{
${ }^{8}$ Son moitos máis os que só presentan formas plenas (Grupo V), con distintas grafías. Indícase entre parénteses o número de rexistros: RVP-05 (1), DE-07 (5), AC-12 (1), CR-12 (2), AC-13 (2), MPA2-13 (2), APP-22 (6), PB1-23 (1), NPD2-28 (1), CLB-33 (3), DAS-36 (7), DGM-36 (1), TP-36 (4), C1836-43 (2).
} 
Con seren fenómenos relacionados, non se pode concluír que afecten aos mesmos autores nin da mesma maneira. Na Táboa 3 compárase o seu comportamento nos dous contextos, indicando en cada caso a que grupo pertence e o número de ocorrencias (forma reducida / forma plena), que consignamos unha vez máis porque en ocasións é tan baixo que resulta pouco significativo. Non é o caso de Pedro Boado, con abundantes testemuños que evidencian unha clara opción inversa, de $n$ - ante o verbo e de non co clítico); e non é o único que muda de preferencias (Fandiño, Pintos, o autor de PC-36, Pol...).

\begin{tabular}{|c|c|c|}
\hline Autores E OBRAS & POSICIÓN ANTEVERBAL & Pronome acusativo \\
\hline LSSA-08 & I: $2 / 0$ & -- \\
\hline RM-44 & I: $3 / 0$ & -- \\
\hline $\mathrm{ABF}$ & II: 12 / 8 & III: 3 / 3 \\
\hline PBS-23 & II: $11 / 3$ & IV: $1 / 10$ \\
\hline OSP $1-40$ & III: 2 / 1 & I: $4 / 0$ \\
\hline RVV-sd & III: $1 / 1$ & I: $2 / 0$ \\
\hline CCX-46 & III: 3 / 3 & III: $1 / 1$ \\
\hline JMP & III: $6 / 5$ & IV: $1 / 3$ \\
\hline APP-22 & III: $1 / 1$ & $\mathrm{~V}: 0 / 6$ \\
\hline OPG[GF]-37 & IV: $1 / 3$ & -- \\
\hline PC-36 & IV: $3 / 40$ & II: $9 / 5$ \\
\hline $\mathrm{FP}$ & IV: $4 / 8$ & II: 3 / 1 \\
\hline DE-07 & IV: $4 / 17$ & $\mathrm{~V}: 0 / 5$ \\
\hline MPA & IV: $3 / 15$ & $\mathrm{~V}: 0 / 2$ \\
\hline C1836-43 & IV: $2 / 4$ & $\mathrm{~V}: 0 / 2$ \\
\hline DDF-20 & $\mathrm{V}: 0 / 4$ & I: $2 / 0$ \\
\hline TQ-20 & $V: 0 / 21$ & III: 2 / 2 \\
\hline VT & $\mathrm{V}: 0 / 12$ & III: $1 / 1$ \\
\hline PG-10 & $\mathrm{V}: 0 / 17$ & IV: $1 / 6$ \\
\hline CFRA-13 & $\mathrm{V}: 0 / 10$ & IV: $1 / 2$ \\
\hline CPCh-37 & $\mathrm{V}: 0 / 5$ & IV: $1 / 3$ \\
\hline
\end{tabular}

Táboa 3. Cotexo do uso da forma reducida con verbos e con pronomes acusativos 3P 
3. Hai aínda un terceiro contexto de interese para a morfoloxía do adverbio non, pois ante outros clíticos pode perder a nasal final, maiormente se o que segue comeza por nasal ${ }^{9}$. Nestes textos atopamos non me \{non me, nonme\} e no me \{no me, no'me, no-me, nome\}, non nos \{non nos\} e no nos \{no nos, no'nos, no-nos, nonos\}, non lle(s) e no lle(s), non se e no se. Coma adoito, mostramos só os datos das obras que teñen formas reducidas.

\begin{tabular}{|c|c|c|c|c|c|c|c|c|c|c|c|}
\hline & \multicolumn{2}{|c|}{$\begin{array}{l}\text { PRON. } \\
M E\end{array}$} & \multicolumn{2}{|c|}{$\begin{array}{l}\text { PRON. } \\
\text { NOS }\end{array}$} & \multicolumn{2}{|c|}{$\begin{array}{l}\text { PRON. } \\
L L E(S)\end{array}$} & \multicolumn{2}{|c|}{$\begin{array}{l}\text { PRON. } \\
\quad S E\end{array}$} & \multicolumn{2}{|c|}{ TotaIs } & \multirow{2}{*}{ Tendencia } \\
\hline & no & non & no & non & no & non & no & non & $\begin{array}{c}\text { nom-Inon-I } \\
\text { noll-Inos-Inon }\end{array}$ & REDUCIDA/PLENA & \\
\hline RVP-05 & & & 1 & & 1 & 1 & & 1 & $0 / 1 / 1 / 0 / 2$ & $2 / 2$ & III \\
\hline DE1-07 & 2 & & & & & 6 & & & \multirow{2}{*}{$5 / 0 / 0 / 0 / 17$} & \multirow{2}{*}{$5 / 17$} & \multirow{2}{*}{ IV } \\
\hline DE2-07 & 3 & 2 & & & & 6 & & 3 & & & \\
\hline PG-10 & 1 & 1 & 5 & & & 4 & & 4 & $1 / 5 / 0 / 0 / 9$ & $6 / 9$ & IV \\
\hline AC-12 & 1 & & 1 & & & & & & $1 / 1 / 0 / 0 / 0$ & $2 / 0$ & I \\
\hline CR-12 & & & 2 & & & 1 & & 5 & $0 / 2 / 0 / 0 / 6$ & $2 / 6$ & IV \\
\hline CFRA-13 & 2 & & 1 & & & & & 13 & 2/1/0/0/13 & $3 / 13$ & IV \\
\hline CCBM-13 & 1 & 1 & & & & & & & $1 / 0 / 0 / 0 / 1$ & $1 / 1$ & III \\
\hline DDF-20 & 1 & & & & & & & 3 & $1 / 0 / 0 / 0 / 3$ & $1 / 3$ & IV \\
\hline MPA6-20 & & & & & 1 & & & & $0 / 0 / 1 / 0 / 0$ & $1 / 0$ & I \\
\hline TQ2-20 & 1 & 2 & & 1 & & 7 & & 3 & $1 / 0 / 0 / 0 / 13$ & $1 / 13$ & IV \\
\hline APP-22 & 1 & & & & & & & 3 & $1 / 0 / 0 / 0 / 3$ & $1 / 3$ & IV \\
\hline PBS-23 & 5 & 1 & & & & 13 & & 17 & $5 / 0 / 0 / 0 / 31$ & $5 / 31$ & IV \\
\hline ТР2-36 & 1 & 2 & 4 & & & 5 & & 2 & $1 / 4 / 0 / 0 / 9$ & $5 / 9$ & IV \\
\hline CPCh-37 & 2 & 2 & & & & 5 & & 7 & $2 / 0 / 0 / 0 / 14$ & $2 / 14$ & IV \\
\hline OSP1-40 & & & 1 & & & 1 & & & $0 / 1 / 0 / 0 / 1$ & $1 / 1$ & III \\
\hline C1836-43 & 2 & & 1 & & & 1 & & 3 & $2 / 1 / 0 / 0 / 4$ & $3 / 4$ & III \\
\hline JMP1-43 & 1 & & & & & & & & $1 / 0 / 0 / 0 / 0$ & $1 / 0$ & I \\
\hline MV2-45 & 1 & & & & & & & & $1 / 0 / 0 / 0 / 0$ & $1 / 0$ & I \\
\hline
\end{tabular}

Táboa 4. Presenza relativa de $\{n o, n o n\}$ ante clíticos comezados por consoante

\footnotetext{
9 Forma parte do fenómeno enunciado deste xeito por Marcial Valladares, na súa gramática: "en gracia, si se quiere, de la eufonía, podrá suprimirse, á medio del trait d’union, la $n$ última seguida de otra $n$, del afijo me, ó de los adverbios máis, menos. Por ejemplo: no-nos dèijes = no nos dejes; no-m’acòrdo = no me acuerdo; no-máis guerra = no mas guerra; no-menos que ti = no menos que tu" (1970: 106).
} 
Mostran unha práctica que ten interese para o noso propósito, mais non ao nivel da comentada nas alíneas anteriores, xa que en boa medida o fenómeno se sitúa no plano da representación gráfica; isto é, a escrita $<$ no-me $>$, p. ex., reproduce unha secuencia fónica con esa redución, pero esta pode existir igualmente de forma constante e habitual tamén nos que grafan $<$ non me>.

\section{A MARCA DE NÚMERO NO CLÍTICO DATIVO DE 3P}

\subsection{Lles lle}

En galego é frecuente o uso de lle como forma sincrética ('lle, lles'), sen o morfo de número que diferencia o par lle: lles. Ocorre isto de maneira habitual na lingua espontánea da Galicia occidental e meridional (Mapa 2: área B), onde os falantes só usan lles cando precisan marcar que o referente é plural; mais tamén no cuartel nororiental, onde se diferencia adoito entre lle sg. e lles pl., os falantes tenden a usar a forma sincrética en determinados contextos sintagmáticos (p. ex. dixenlle(s) algo a eles $)^{10}$. Para a maior parte dos usuarios este é un trazo espontáneo, sobre o que non reflexionan, e iso faino especialmente interesante para o noso propósito caracterizador, sobre todo nunha altura en que a aprendizaxe escolar aínda non chamara a atención sobre esta diferenza no uso entre falantes galegófonos. Non se descarta, con todo, que a presión académica e a corrección lingüística en español puidesen mediatizar o uso dos autores do noso corpus, ampliando a presenza de lles máis aló do seu uso natural; mais, xusto nesas circunstancias, a escolla de lle pl. seguiría sendo moi significativa.

1. Son minoría as obras que non presentan variación entre lle e lles como forma de plural (20 sobre 49), e polo xeral con moi baixo número de ocorrencias;

10 Non é o lugar de expońermos polo miúdo cales son os posibles contextos e o comportamento habitual dos falantes en cada un deles (descritos sucintamente en Álvarez 1998: 79-80). Digamos a modo de exemplo que un falante da área A escollerá sempre lles nun esquema do tipo "A eles déronlles algo" (e déronllelo), pero que nun esquema de redobro, coma "Dálles iso a eles", a mesma persoa escollerá moi probablemente lle (e déronllo como alternativa a déronllelo). Un falante da área B preferirá lle en ámbolos casos, pois só seleccionará lles cando sinta a necesidade, con frecuencia contrastiva, de marcar o trazo 'plural' (e sempre dirá déronllo, sen máis opción). A área C é de transición: úsase adoito lles coma na área A, pero a amálgama é polo xeral $l l o$, forma característica da área B. 
ademais, cómpre dicir que algunhas delas son de autores que presentan alternancia noutros textos, como se pode comprobar na Táboa 5. De maneira case xeral, a falta de variación débese a que só se usa a canónica lles: ben é certo que en moitas obras o número de ocorrencias é tamén pouco significativo (con 1 só rexistro: ABF112, MPA3-14, PB1-23, NPD2-28, JMP1-43, FA2-45 e MV4-46; con 2 rexistros, NPD1-26-28, VT1-29, CLB-33, DGM-36, FA1-42 e JMP3-45); por iso destacan, tanto pola abundancia de rexistros coma pola constancia da escolla, VT5-45 (4), CR-12 (6), OPG[RV]-37 (9) e, sobre todo, MPA2-13 (10), MPA6-20 (11) e TQ2-20 (13). En sentido contrario, con lle pl., só contamos co caso excepcional de VT4-43 (1).

O Grupo I, que estaría formado por aqueles que sempre ofrecesen a forma sincrética, está baleiro ${ }^{11}$. O Grupo V, marcado pola constancia de lles, está integrado polas obras relacionadas no parágrafo anterior, sempre que non pertenzan a autores que presentan variación noutros textos.

2. É máis frecuente que lle e lles concorran como formas de plural nun mesmo texto (29 obras), se ben en distintos graos e con desigual número de aboacións; con todo, a primeira observación é o predominio xeral da forma con marcas explícitas de plural.

A Táboa 5 mostra as porcentaxes de uso de lles en obras ou en escritores que mostran alternancia. Nela agrúpanse as obras supostas dun mesmo autor e ordénanse, segundo a incidencia da forma marcada fronte á sincrética, en tres treitos. No inicial, Grupo II, figuran os poucos autores en que lles aparece con menos do $40 \%$ das ocorrencias. No Grupo IV lístanse aqueles en que se produce a situación inversa, pois é lle a variante que non acada o $40 \%$ dos rexistros; repárese no alto número de atestacións nalgunhas destas obras, dándolle un valor especial á constancia da escolla lles ou, visto do outro lado, á excepcionalidade de lle. No treito intermedio (Grupo III) colocamos as obras de porcentaxes máis próximas, en principio con lles entre o $40 \%$ e o $60 \%$, mais na práctica cunha proporción igual ou superior á metade das ocorrencias.

11 A única obra que podería integralo pertence a Turnes (VT4-43), que presenta variación noutros textos. 


\begin{tabular}{|c|c|c|c|c|c|c|c|c|c|c|c|}
\hline \multicolumn{4}{|c|}{$\begin{array}{c}\text { Grupo II } \\
\text { Predominio de } L L E\end{array}$} & \multicolumn{4}{|c|}{$\begin{array}{c}\text { GRUPO III } \\
\text { INCIDENCIA SIMILAR }\end{array}$} & \multicolumn{4}{|c|}{$\begin{array}{c}\text { Grupo IV } \\
\text { Predominio de } L L E S\end{array}$} \\
\hline OBRA & lle & lles & $\%$ lles & OBRA & lle & lles & $\%$ lles & OBRA & lle & lles & $\%$ lles \\
\hline C1836-43 & 3 & 1 & $25,00 \%$ & AC- 12 & 3 & 3 & $50,00 \%$ & AAT-05-12 & 1 & 2 & $66,67 \%$ \\
\hline DDF-20 & 2 & 1 & $33,33 \%$ & CCBM-13 & 1 & 1 & $50,00 \%$ & RVP-05 & 1 & 2 & $66,67 \%$ \\
\hline FP1-38 & 4 & 4 & \multirow{2}{*}{$38,89 \%$} & OPG[GF]-37 & 4 & 5 & $55,56 \%$ & DE1-07 & 5 & 5 & \multirow{2}{*}{$68,18 \%$} \\
\hline FP2-sd & 7 & 3 & & CCX-46 & 4 & 5 & $55,56 \%$ & DE2-07 & 2 & 10 & \\
\hline & & & & CPCh-37 & 3 & 4 & $57,14 \%$ & VT1-29 & 0 & 2 & \multirow{5}{*}{$69,23 \%$} \\
\hline & & & & & & & & VT3-42 & 2 & 1 & \\
\hline & & & & & & & & VT4-43 & 1 & 0 & \\
\hline & & & & & & & & VT5-45 & 0 & 4 & \\
\hline & & & & & & & & VT7-46 & 1 & 2 & \\
\hline & & & & & & & & OAS-01 & 1 & 3 & $75,00 \%$ \\
\hline & & & & & & & & DAS1-36 & 1 & 8 & \multirow{3}{*}{$77,78 \%$} \\
\hline & & & & & & & & DAS2-36 & 2 & 3 & \\
\hline & & & & & & & & DAS3-36 & 1 & 3 & \\
\hline & & & & & & & & APP-22 & 1 & 4 & $80,00 \%$ \\
\hline & & & & & & & & OSP1-40 & 1 & 4 & $80,00 \%$ \\
\hline & & & & & & & & TP1-36 & 2 & 3 & \multirow{2}{*}{$81,25 \%$} \\
\hline & & & & & & & & ТР2-36 & 1 & 10 & \\
\hline & & & & & & & & CFRA-13 & 1 & 6 & $85,71 \%$ \\
\hline & & & & & & & & TQ1-20 & 4 & 16 & \multirow{2}{*}{$87,88 \%$} \\
\hline & & & & & & & & TQ2-20 & 0 & 13 & \\
\hline & & & & & & & & PBS-23 & 2 & 15 & $88,24 \%$ \\
\hline & & & & & & & & OPG[RV]-37 & 0 & 9 & \multirow{2}{*}{$90,91 \%$} \\
\hline & & & & & & & & RVV-sd & 1 & 1 & \\
\hline & & & & & & & & PG-10 & 3 & 54 & $94,74 \%$ \\
\hline & & & & & & & & PC-36 & 1 & 29 & $96,67 \%$ \\
\hline
\end{tabular}

Táboa 5. Presenza relativa de $\{/ / e, / / e s\}$ en Papés

3. Se identificamos os autores coñecidos, comprobamos que, con maior ou menor número de testemuños, Fandiño (1), Valladares (1), Pintos (3), Añón (3), N. P. Díaz (3) e Pardo de Andrade (22) se atopan no Grupo V, entre os que só ofrecen lles como plural, sen que obste a procedencia occidental da maior parte deles. En cambio, o compostelán Vicente Turnes móstrase vacilante (Grupo IV), dentro dun mesmo texto ou entre as distintas obras, en maior medida có dezao Varela, quen só fai unha excepción no uso constante da forma marcada (lles: 
OPG[RV]-37 [9]; lle-lles: RVV-sd [1/1]); tamén oscilan entre as dúas variantes Arias Teixeiro, Boado Sánchez, Fernández Neira, Gómez del Ferrol, Pol e Fernández Magariños.

A maior parte dos anónimos mostra tamén, de maneira xeneralizada, esa vacilación. Só catro deles presentan de xeito exclusivo lles (Grupo V), ben que algún con rexistro único: a conversa remitida desde Betanzos (CLB-33 [2]), a carta recomendada compostelá (CR-12 [6]), o diálogo coruñés de Gorecho e Mingos (DGM-36 [2]) e o poema aos insurrectos de Burón (PB1-23 [1]). Aínda que supomos un mesmo autor para os dous textos da Quintana (TQ-20), a práctica é neles diverxente: no primeiro oscila entre lle e lles (4/16) e no segundo opta sempre por lles (13r). Tamén DE-07 e TP-36 mostran un cambio similar entre as dúas entregas, cun uso case exclusivo de lles na segunda, coma se entre unha e outra se tomase conciencia da conveniencia de modificar ese trazo; en cambio, en DAS-36 prodúcese unha situación similar nos tres textos.

\subsection{Llelo 1lo}

É sabido que na maior parte do territorio galego son descoñecidas as formas amalgamadas do tipo llelo e que no seu canto se emprega uniformemente a variante sincrética $l l o$, coma en portugués: na práctica deses falantes, díxenllo significa tanto 'díxenllo (a el, a ela, a vostede)' coma 'dixenllelo (a eles, a elas, a vostedes)'. É este un deses trazos dialectais — coma alálaló, que será tratado máis adiante - nos que se aprecia a retirada en dirección nordés dunha variante, nun proceso de cambio que se vén dando desde a Idade Media ${ }^{12}$.

O Mapa 2 mostra a situación contemporánea, con datos das derradeiras décadas do século XX. Na área marcada como $\mathrm{B}$, llelo descońécese por completo (A eles non llo digas); non por acaso, a variante de dativo lles só se usa nela como forma marcada, segundo foi exposto máis arriba. Na área A llelo é habitual e úsase de

${ }_{12}$ A forma primitiva é $l l o$, formada nunha época en que ilLi só tiña descendentes rematados en vogal. Lles nace a partir de lle, e na súa secuencia fórmase a amálgama llelo, que fai serie con nolo e volo. Na época medieval, a innovación llelo prosperou na maior parte do territorio galego, con maior ou menor incidencia segundo as rexións; só no galego suroccidental se seguiu usando de forma constante a primitiva llo 'llelo’ (Álvarez 1996). O mapa actual mostra que, finalmente, esa innovación non se consolidou en todo o territorio que participou nela e que a fronteira recúa desde entón en dirección norte e en dirección leste. 
regra na maior parte dos posibles contextos sintácticos e informativos ( $A$ eles non llelo digas), o mesmo cá variante de dativo lles (cf. supra); con todo, nos espazos urbanos desta área decrece a frecuencia de $l l e l o$, en beneficio de $l l o$, e nalgunhas zonas tamén se observa certa desafección por ela en grupos de falantes novos. A área C é unha zona de transición, consecuencia do repregamento mencionado, na que se dan testemuños de llelo de forma menos constante — cando non esporádica-, polo xeral en falantes marcados socialmente como moi conservadores; a forma de dativo plural é adoito lles, coma na área $\mathrm{A}$, mais tamén comeza a recuar.

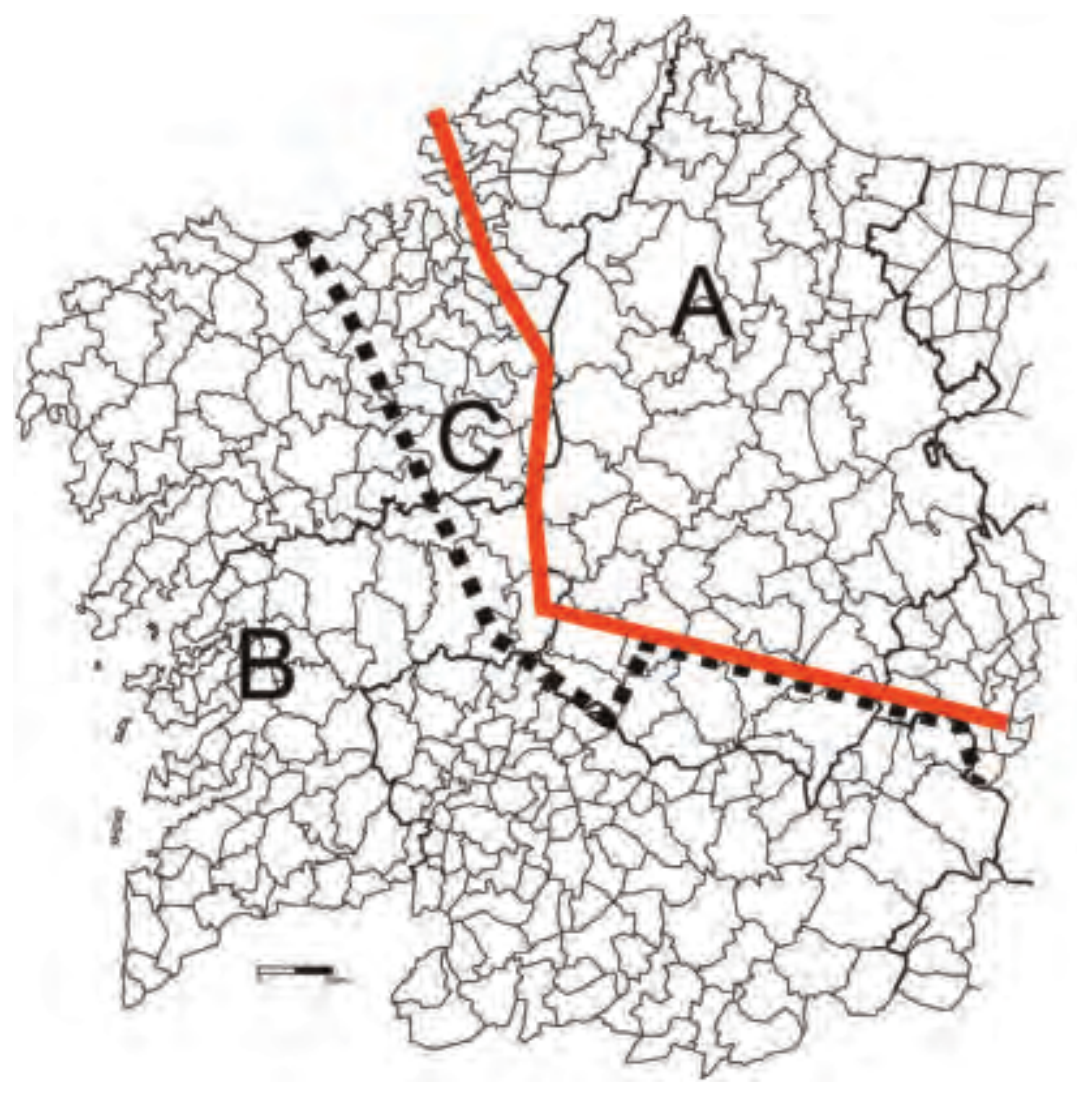

Mapa 2: Distribución territorial de $\{/ / e s$, I/e $\}$ plural e da amálgama pronominal /lelo /lo. Fonte: Álvarez 1998 
É moi improbable que un autor das primeiras décadas do século XIX adoptase llelo se non formaba parte do seu inventario pronominal (non temos máis ca lembrar o esforzo que nos supón aos que temos que asumila e ensinala, desde que foi declarada forma estándar). Ao non estar a variante llelo implicada nun proceso de cambio inducido naquel entón, debemos aceptar que a súa presenza se debe ás características diatópicas da lingua do autor. No corpus, con significado plural no dativo, só atopamos 36 exemplos repartidos en 14 obras: llo (9r), llos (3r), lla (3r), llas (10r); llelo (7r), Llelos (1), llela (3r $)^{13}$.

\begin{tabular}{|c|c|c|c|c|c|c|c|c|c|c|c|c|c|}
\hline \multicolumn{2}{|c|}{$\begin{array}{l}\text { GRUPo I } \\
\text { Uso EXCLUSI- } \\
\text { VO DE } L L O\end{array}$} & \multicolumn{4}{|c|}{$\begin{array}{c}\text { Grupo II } \\
\text { Predominio de } L L O\end{array}$} & \multicolumn{4}{|c|}{$\begin{array}{c}\text { GRUPO III } \\
\text { INCIDENCIA SIMILAR }\end{array}$} & \multicolumn{4}{|c|}{$\begin{array}{c}\text { Grupo IV } \\
\text { Predominio de } L L E L O\end{array}$} \\
\hline OBRAS & llo & OBRAS & llelo & llo & \% llelo & OBRAS & llelo & llo & \% llelo & OBRAS & llelo & llo & \% llelo \\
\hline PG-10 & 4 & PC-36 & 1 & 6 & 14,29 & FP1-38 & 1 & 1 & 50,00 & PBS-23 & 5 & 3 & 62,50 \\
\hline CFRA-13 & 1 & DAS1-36 & & 1 & \multirow{2}{*}{33,33} & & & & & OPG[RV]-37 & 2 & 1 & 66,67 \\
\hline AC- 12 & 21 & DAS2-36 & 1 & 1 & & & & & & TQ1-20 & 1 & 0 & 100,00 \\
\hline MPA2-13 & 1 & & & & & & & & & & & & \\
\hline TC-36 & 1 & & & & & & & & & & & & \\
\hline CPCh-37 & 2 & & & & & & & & & & & & \\
\hline OSP1-40 & 1 & & & & & & & & & & & & \\
\hline
\end{tabular}

Táboa 6: Ocorrencias da amálgama 'lles+o(s), Iles+a(s)'

O baixo número de rexistros obriga a actuar con moita cautela, pero non impide facermos algunhas observacións nin obtermos información de interese. Como era de esperar, neste corpus textual dominan as amálgamas reducidas, propias da Galicia occidental, e nalgúns textos só se usa $l l o(s)$, lla(s). De acordo co mapa actual, é congruente a práctica seguida polo noiés Ramón Malvárez (se é el o autor de CPCh-37 [2r]), polos composteláns ocultos tras os pseudónimos Xan de Mingucho (AC-12 [2r]) e F.R.A. (CFRA-13), polo descońecido autor de TC-36, que tamén supoñemos santiagués, e mais por Manuel Fernández Maga-

${ }_{13}$ Coas grafías <llo, ll'ò, lle lo, lle-lo; llos, lle los; lla, llela, lle la; llas >. Con significado singular no dativo obtemos os seguintes datos: llo (34), l'-o (1); llos (7); lla (29), la (1); llas (8). 
riños, residente en Santiago (OSP1-40) ${ }^{14}$. Por contra, sorprende este trazo en José Fernández Neira (PG-10 [4r]) e en Manuel Pardo de Andrade (MPA2-13), que proceden dunha bisbarra en que llelo tińa que ser daquela habitual (Mapa 2): ¿significará iso que no galego urbano da Coruña xa non eran de uso común?, ¿el será que a perda observable hoxe nas Mariñas se manifestaba xa entón?

Con todo, nalgúns diálogos de ambiente compostelán tamén hai testemuños ocasionais de llelo. Así ocorre no único rexistro posible de TQ1-20, en DAS-36 ( 2 llo / 1 llelo) e en PC-36 (6 llo / 1 llelo). Estes son os contextos de uso de ámbalas variantes nestas obras:

\section{LLELO, LLELA, LLELOS, LLELAS ～LLO, LLA, LLOS, LLAS ‘llelo, llela, llelos, llelas’}

TQ1-20: Eu arrendollela oxê polo presio (198).

DAS2-36: Dios lle lo pague. (261). PC-36: é cando ó Santo Samuel lle pideu rey ó pueblo, nin pideu reina nin Dios lle la deu sinon q[u]e nomeou á Saul (681).
DAS1-36: o mesmo que facerlles pagalas armas ós proves cando llas levaron á forza (71).

DAS2-36: Eso paroleyno eu, por que llo oira á uns Señores na Rua do Villar. (192).

PC-36: é en moitisimas ocasiôs, non esperaron á $\mathrm{q}[\mathrm{u}] \mathrm{e}$ llo pidisen, sinon $\mathrm{q}[\mathrm{u}] \mathrm{e}$ se adelantaron voluntariamente (411).

PC-36: pouco importa darlles casas, sinon hay pan; prô nò suposto que faltasen casas, non contribuirian prâ facerllas? (644).

PC-36: é estonces deulle as tablas dá ley por escrito, entregoullas á Moises é Aaron cabezas dôs q[u]e creian nel (190).

PC-36: si carlos as pede danllas si ó demo llas pede dânllas, si as formigas llas peden danllas (771).

Nos tres exemplos de DAS2 atopámonos ante situacións distintas, e na diferenza pode estar a motivación da escolla. No primeiro, Farruco responde conxuntamente "Dios lle lo pague" ás catro persoas que saúdan con fórmulas xaculatorias o seu espirro ("Dominus técum", "Dios te axûde"); o uso de singular podería ser descortés

${ }^{14}$ Non atopamos noticias biográficas de Manuel Fernández Magarińos, a pesar de que os seus pregos saíron en Santiago espallados por tres décadas. O Seor Pedro ten trazos que non desmenten unha localización preferentemente occidental, con algún trazo central. A lingua empregada podería ser santiaguesa ou dunha modalidade semellante. En todo caso, o único exemplo do fenómeno estudado está en contexto de redobro, polo que incluso na área A sería admisible llo (a par de llelo): "é dimpois dádello os Cas, que lles faga bo porveito" (103-104). 
para as tres que se considerasen excluídas, entre elas o Cura, que falou de primeiro e en latín. Nos outros dous non precisa recorrer á forma marcada como plural: nun está ben explícito o número no clítico e frase correferentes situados no contexto previo inmediato ("facerlles... ós proves"); o outro é un esquema de redobro (“... llo... á uns señores"), no que incluso os falantes da área A (Mapa 2) usan adoito a forma sincrética. En cambio, o autor de PC-36 parece ter unha práctica xeral de uso da forma sincrética, pero na única ocasión en que emprega a forma lle la explota o recurso ata os lindeiros da corrección gramatical: posto que hai dous demandantes sucesivos (o pobo pediulle ao seu sacerdote, Samuel, que lle pedise a Deus un rei), é posible que o autor use o plural para se referir ad sensum ao "pueblo" (substantivo singular) como destinatario colectivo (fronte a Samuel, só un intermediario).

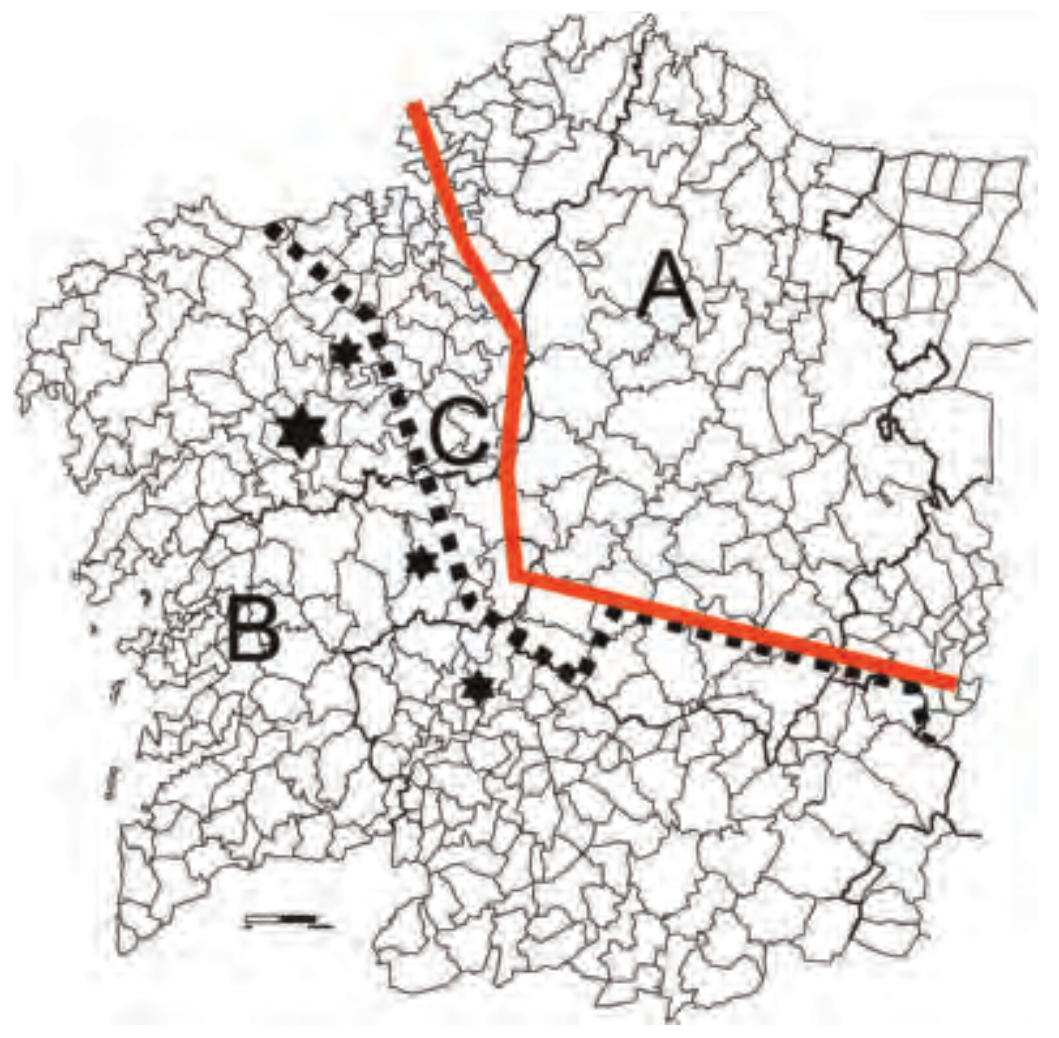

Mapa 3: Localización espacial dos testemuños de /lelo presentes en Papés ${ }^{15}$

${ }^{15}$ A estrela de maior tamaño representa conxuntamente os testemuños dos anónimos composteláns citados. 
Hai aínda outros tres autores que alternan llo e llelo co mesmo significado plural. O primeiro é Pedro Boado Sánchez, que Carballo (1975: 43) localiza como nacido na aldea de Quintás (Santa María da Barra-Coles) ${ }^{16}$, ao sur do lugar dos Peares, onde empatan o Sil e o Miño, e por tanto fóra da área máxima actual de llelo (Mapa 3). De oito ocasións posibles, o ourensán Boado só emprega a forma sincrética en tres: advírtase no exemplo repetido ao comezo das dúas columnas a alternancia "llo... lle lo" co mesmo referente; tamén a presenza da forma sincrética no único contexto de redobro ("llo... aos curas").

\section{LLELO, LLELA, LLELOS, LLELAS}

PBS-23: A min, do meu corto entender parecíame que s'os Curas se contentasen c'o que se lles dese por devocion sin pedilo, nin facer outras cousas pra que $\underline{\text { lo }}$ dean, ou pra que lle lo paguen, pase, é mais ainda moytas veces habian de salir millor, qu' entre gente labradora hay moyta caridá (740).

PBS-23: sin ter un ben de Dios, nin siquera un pedazo de pan que levar á boca, que todo lle lo vendera á Justicia pra pagar á ofrenda do enterro do amo da casa (504).

PBS-23: é mais ben saben acudir á justicia se non lle lo dan logo, ou lles falta algo. (720).

PBS-23: ainda mais de catro m' habian de ir á rogar por èl: mais esso de lle lo dar, pra lelo si, pro non pra levalo (567). PBS-23: é un lotiño de berzas é un pouquiño d' unto, com-a-un puño, é todo lle-lo deixou sin decir cas-que nada (517).
LLO, LLA, LLOS, LLAS

'Ilelo, llela, llelos, llelas'

PBS-23: A min, do meu corto entender parecíame que s'os Curas se contentasen c'o que se lles dese por devocion sin pedilo, nin facer outras cousas pra que llo dean, ou pra que lle lo paguen, pase, é mais ainda moytas veces habian de salir millor, qu' entre gente labradora hay moyta caridá (740). PBS-23: No eso, n' hay que 11 ò decir os Curas. ¡S’ alguns d' eles oirán á sua mercè! (156). PBS-23: e tiñan qu' esperar pra casarse: é á vergonza de todos modos, mandase ó que mandase ó señor Obispo, ninguen lla quitaba. (171).

Os outros dous son o autor de OPG[RV]-37, identificado como Ramón Varela Vahamonde, de Lalín (1 llo/2 llelo), e Florencio Pol, de Ordes (1 llo / 1 llelo). Non percibimos ningún criterio de escolla no uso do dezao; advertimos só que na mesma pasaxe da forma sincrética — e co mesmo referente do dativo- emprega tamén lle como

16 Outros cualifícano como "ourensán" — sen precisar se o xentilicio se refire á vila ou á provincia—e como monfortino. A conexión por vía materna coa familia Sánchez da Somoza, que recolle Carballo (1975: 43n), vincúlao tamén de forma especial ás terras do sur de Lugo. 
plural. En Florencio Pol, ademais da concorrencia de lle pl., obsérvase que a forma sincrética ocorre nun esquema de topicalización (“que... ós señores que... llelas...”).

\section{LLELO, LLELA, LLELOS, LLELAS}

OPG[RV]-37: pero eu escarmentéi, que por mais voltas que deron, mais gota non lle la dei (90). OPG[RV]-37: ademais dos cartos, queren tamén os regalos; mais se foran sabañós, tercianas, e constipados, eu lle los regalaría pra que os levasen os diablos (171).

FP1-38: Ti ben os aconsellache que samasen coma hirmaus, que nandivesen á paus pro en valde lle lo enseńache (782).
LLO, LLA, LLOS, LLAS

'llelo, llela, llelos, llelas'

OPG[RV]-37: Pero logo que o soupen díxenllas con gran descaro: «Veña pr' acá o proceso, que hey de coller e rachalo». Mala palabra lle dixen, que como estaban culpados, tratáronme de ruin, de chulo, cornudo, gafo (238).

FP1-38: Co promeiro que faria polo ben dos labradores, dixo, que lle acortaria tantas pagas e os sińores que tamen llas sacaria, Caso fose Diputado (417).

Se situamos estes testemuños no territorio (Mapa 3), comprobamos que desde a primeira metade do século XIX a isoglosa se desprazou en dirección nordés, como xa foi indicado. Posto que algúns textos anónimos composteláns, que non todos, recollen este trazo, cabe supońer que os posibles autores responden a esta característica diatópica e que reproducen un trazo que os vincula con maior verosimilitude na contorna leste da comarca.

\section{NINGUÉN, NADIA, NAIDE}

Entre os pronomes cuantificadores existenciais, o galego conta cunha unidade autónoma co significado negativo 'ningunha persoa' (Álvarez/Xove 2002: 486). A forma máis común é ninguén (con algunhas variantes fónicas), que é tamén a estándar, pero a ninguén se lle escapa que moitos galegofalantes usan de xeito equivalente outras formas. O Mapa 4 mostra a distribución territorial das variantes recollidas na década dos 70 do século pasado ( $A L G a$ : II 260r), que cómpre analizar antes de presentar os datos ofrecidos polos textos que nos convocan. 


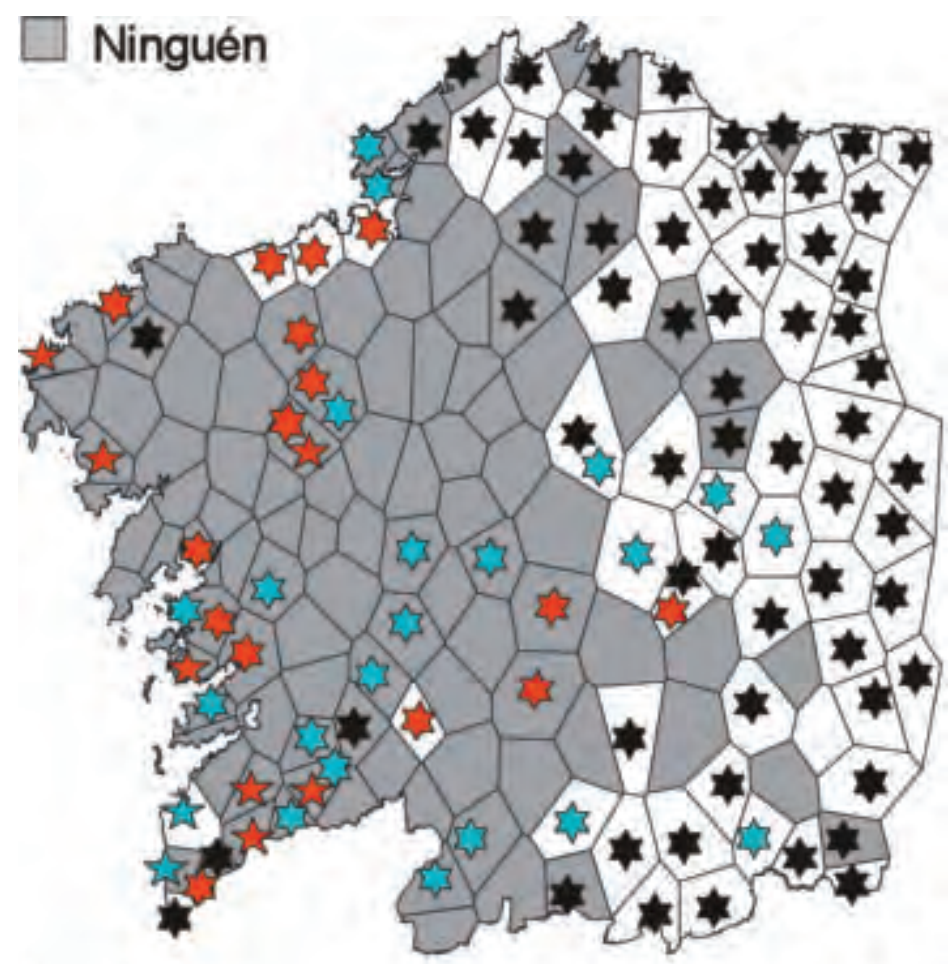

Naide

Nadia

Nadias $\star$

Nadie

\section{nadies $t$}

Mapa 4: Ninguén, nadia, naide, nadie. Elaboración a partir de ALGa: II 260

Cartografamos de xeito diferente os derivados de ${ }^{*}$ NE-QUEM, sombreado, e os descendentes do participio NATI, con estrelas de distintas formas e cores. Se nos concentramos na mancha gris, percibimos que é bastante compacta na metade occidental pero non na oriental. Á vista do mapa, aínda que non podemos asegurar que ninguén existiu outrora con plena vixencia en todo o territorio galegófono, si podemos deducir que houbo un retroceso cara a occidente, pois 
os testemuños desagregados que se ven na metade oriental do mapa non son indicios do avance cara ao leste, senón pegadas dunha extensión outrora maior ${ }^{17}$. As estrelas negras mostran unha área compacta na parte oriental, onde naide é adoito forma única; non por acaso, quizais, o primeiro testemuño dos descendentes de NATI procede da estrema oriental do territorio galego-portugués (nade, nadie, 1280-90, FRC; fonte TMILG, onde son os únicos rexistros medievais de \{naide, nadie, nade\}). No territorio mindoniense, naide é a variante predominante e a que os falantes de tódalas idades identifican como propia e característica da súa variedade ; iso non obsta para que nalgúns lugares conviva con ninguén. Naide ten presenza isolada ocasional no occidente de Galicia, con certa concentración na área tudense, que en moitos aspectos lingüísticos garda similitude coa parte oriental.

As estrelas vermellas, que representan a nadia (< nadi ha, Corominas: s.v. NADIE) e nadias, debuxan unha mancha occidental, complementaria da anterior, que nalgún tempo debeu de ser compacta: ocuparía, cando menos, o territorio do bloque occidental, cunha derivación central que segue o curso do Miño e o Sil. Esta área é a máis feble e fragmentaria, como consecuencia dun proceso de cambio no que xogan factores de prestixio: abandónase nadia, que se interpreta (erroneamente) como pronuncia deturpada propia de persoas iletradas (e maiores), e ascende nadie, seguindo o patrón do español.

A variante nadie está representada polas estrelas azuis. Non hai na súa forma nada que a delate orixinariamente como castelanismo, pero é indubitable que a coincidencia formal lle engade un prestixio extra sobre as outras variantes e a axuda a prosperar. Ollando o mapa, vemos que non ten un territorio compacto e semella que se estende a expensas de nadia(s), sobre todo, e tamén de naide. Tamén Saco debeu entender que a única forma espúrea era nadie, que non inclúe na súa gramática, onde en cambio acolle por igual e sen reservas ninguén, naide e nadia (1868: 61).

\footnotetext{
17 As atestacións máis antigas de ninguén proceden, precisamente, do oriente e centro de Galicia, 1268Vilafranca e 1300Sobrado; na mesma área existía, asemade, a variante ningún co mesmo valor absoluto (Monteagudo 2008: 226). Remitimos á mesma obra para o estudo dos primeiros pasos de nullo, ninguén e ningún (autónomo).
} 
Nos nosos textos atopamos as variantes ninguén \{ninguén, ninguèn, ninguen, ningen\}, nadia, naide e nadie. Non nos imos deter na forma maioritaria ninguén, para centrar o noso interese e a nosa análise nas outras variantes ${ }^{18}$. Entre estas óptase, de xeito que non aparece máis dunha variante por texto/autor:

- Os únicos que empregan a occidental nadia, sempre en concorrencia con ninguén, son os autores anónimos de DAS1-36 (ninguen [2r], nadia [1r]) e CCX-46 (ninguen [1r], nadia [1r]), e mais Vicente Turnes (VT4-43: ningen [1r]; VT5-45: nadia [1r]).

- Escollen a centro-oriental naide, con senllos rexistros, Manuel Fernández Magarińos, os autores anónimos de TQ1-20 e PC-36, e mais, como era de esperar, o mindoniense Nicomedes Pastor Díaz. A segunda entrega da Tertulia da Quintana (TQ2-20) testemuña a concorrencia de ninguèn (1r); tamén o autor de PC-36 acolle ninguen (2r). Estes datos suxiren que na altura o límite entre nadia e naide se situaba na contorna compostelá.

- Optan pola forma coincidente co castelán nadie, con cadanseu rexistro, o notario ordense Florencio Pol (FP2-sd) e mailos autores anónimos de TC36 e TP2-36 (santiagueses) e de DGM-36 (coruñés), testemuñando coa súa práctica que na altura xa estaba en marcha o proceso de substitución de nadia e naide por nadie, polo menos no eixe Coruña-Ordes-Santiago. En TP2-36 concorre con ninguèn (2r) e en Florencio Pol con ninguen (2r: FP1-38, FP3-sd).

- Os únicos que non mostran pegadas de ninguén - e poderían integrar un Grupo $\mathrm{V}^{19}$ — son N. P. Díaz (NPD2-28), Fernández Magariños (OSP1-40) e os anónimos de TC-36 e DGM-36.

18 Testemuñan só variantes de ninguén as seguintes obras e autores: DE1-07 e DE2-07, ABF1-12 e ABF414, CR-12, CFRA-13, MPA2-13, PB2-23, PBS-23, CPCh-37, OPG(RV)-37, C1836-43, RM-44, FA2b-45, JMP2-45 e RVV-sd.

19 Preferimos incluílos dentro do Grupo formado polos que fixeron a mesma opción formal entre os descendentes de NATI. 


\begin{tabular}{|c|c|c|c|c|c|c|c|c|c|c|}
\hline \multicolumn{2}{|c|}{$\begin{array}{c}\text { GrUPo I } \\
\text { Só NINGUEN }\end{array}$} & \multicolumn{3}{|c|}{$\begin{array}{c}\text { GRUPO II } \\
\text { VARIACIÓN CON NADIA }\end{array}$} & \multicolumn{3}{|c|}{$\begin{array}{c}\text { Grupo III } \\
\text { VARIACIÓN CON NAIDE }\end{array}$} & \multicolumn{3}{|c|}{$\begin{array}{c}\text { Grupo IV } \\
\text { VARIACIÓN CON NADIE }\end{array}$} \\
\hline OBRAS & ninguén & OBRAS & ninguén & nadia & OBRAS & ninguén & naide & OBRAS & ninguén & nadie \\
\hline DE1-07 & 3 & DAS1-36 & 2 & 1 & TQ1-20 & & 1 & TC-36 & -- & 1 \\
\hline DE2-07 & 1 & VT4-43 & 1 & & TQ2-20 & 1 & & DGM-36 & -- & 1 \\
\hline ABF $1-12$ & 4 & VT5-45 & & 1 & NPD2-28 & -- & 1 & TP2-36 & 2 & 1 \\
\hline ABF4-14 & 1 & CCX-46 & 1 & 1 & PC-36 & 2 & 1 & FP1-38 & 1 & \\
\hline CR-12 & 2 & & & & OSP $1-40$ & -- & 1 & FP2-sd & & 1 \\
\hline CFRA-13 & 1 & & & & & & & FP3-sd & 1 & \\
\hline MPA2-13 & 1 & & & & & & & & & \\
\hline PB2-23 & 1 & & & & & & & & & \\
\hline PBS-23 & 3 & & & & & & & & & \\
\hline CPCh-37 & 3 & & & & & & & & & \\
\hline OPG[RV]-37 & 1 & & & & & & & & & \\
\hline RVV-sd & 1 & & & & & & & & & \\
\hline C1836-43 & 1 & & & & & & & & & \\
\hline RM-44 & 1 & & & & & & & & & \\
\hline FA2b-45 & 1 & & & & & & & & & \\
\hline JMP2-45 & 1 & & & & & & & & & \\
\hline
\end{tabular}

Táboa 7. Presenza relativa de ninguén e \{nadia, naide, nadie\} en Papés

\section{AS FORMAS DE PLURAL DOS PRONOMES TÓNICOS DE PRIMEIRA E SEGUNDA PERSOAS}

\subsection{Nós $e$ nosoutros, vós $e$ vosoutros}

Nós é vós son as formas maioritarias neste corpus textual — coma na escrita galega en tódolos tempos-, con tres de cada catro rexistros. Na Táboa 8 advírtese que o número de rexistros de $\mathrm{P} 4$ é moito máis elevado, pero a proporción interna das dúas persoas é moi semellante, cunha lixeira vantaxe de nosoutros sobre vosoutros. No cadro, e na análise que segue, tense en conta só o emprego de vós/vosoutros como forma de plural (para vós ' $2 \mathrm{P}$ sg. cortés', véxase máis abaixo $\$ 5.2$ ). 


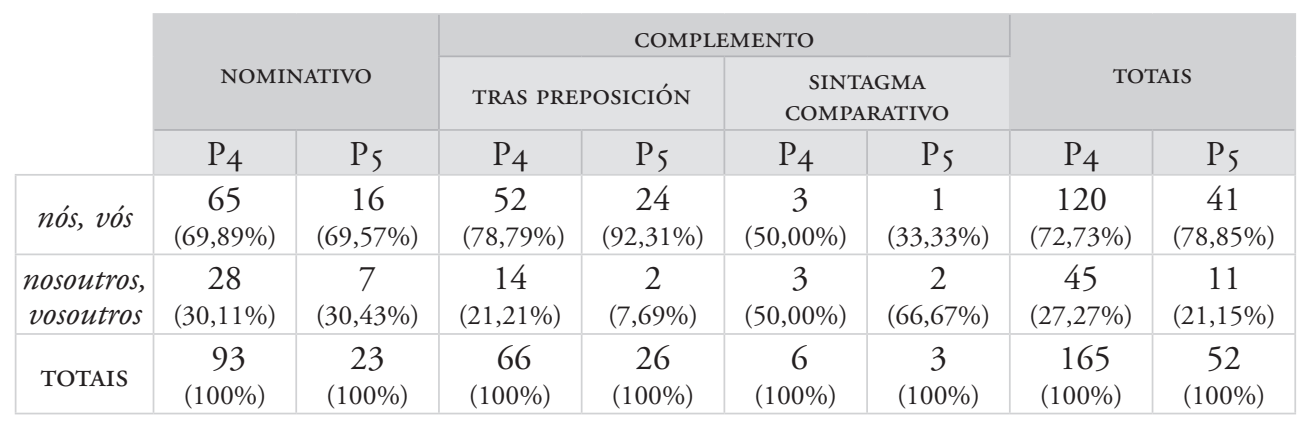

Táboa 8. Cómputo das variantes nós e nosoutros (P4) e vós e vosoutros (P5) en Papés

1. A escolla nós/nosoutros, vós/vosoutros é un importante criterio caracterizador da lingua destes autores. O número de formas é desigual, nuns casos tan baixo que a selección é pouco significativa, mais noutros non parece deixar lugar a dúbidas sobre cal era a opción preferente; por iso, para valorar a incidencia, indicamos en cada caso o número de ocorrencias no corpus (Táboa 9):

- Un bo grupo de textos ou autores presentan só formas reducidas, tanto no nominativo coma no caso complemento (Grupo I).

- Son excepcionais os que empregan só as formas compostas (Grupo V), sempre cun número de rexistros pouco determinante. Con todo, non podemos pasar por alto quen son estes usuarios preferentes de nosoutros, vosoutros: Antonio Benito Fandiño, Pedro Boado Sánchez, Nicomedes Pastor Díaz, Marcial Valladares ${ }^{20}$ e o autor anónimo de DGM-36. Dos coñecidos, só $\mathrm{N}$. P. Díaz pertence á área que denominamos "área nosoutros" por manifestar hoxe un uso normal, non marcado, da forma composta (Álvarez 2010).

- Cando concorren as dúas formas, case sempre é a simple a máis frecuente, en distintos graos. No treito máis elevado, formando o Grupo II, están Florencio Pol, Alberto Camino e dous anónimos, o que supoñemos autor único dos tres diálogos da Alameda e mailo de CFRA-13; séguenlles en orde decrecente Vicente Turnes, o anónimo de PB1-23 e Pardo de Andrade. Nun

${ }^{20} \mathrm{Na}$ súa gramática, Valladares parece dar preferencia ás formas compostas, as únicas que cita na exposición: "Eu, nosoutros, nosoutras son las personas que hablan" (1970: 41-42). As variantes nòs e vòs aparecen incluídas no paradigma, co comentario de que estas valen para ámbolos xéneros, se callar en contraposición non explícita con nosoutros / nosoutras e vosoutros / vosoutras. O uso mostrado nestes textos confirma esa preferencia. 
nivel de equilibro entre ambas (Grupo III) están o anónimo de Cacheiras (PC-36), Fernández Neira, Juan Manuel Pintos, o anónimo de DDF-20 e o que asina como Ramón González Senra (CR-12). Só dous autores deixan en minoría, ben que feble, a forma simple (Grupo IV): Fernández Magariños (OSP1-40) e o anónimo dos dous diálogos dos esterqueiros (DE-07).

\begin{tabular}{|c|c|c|c|c|c|c|c|c|c|c|c|}
\hline \multicolumn{3}{|c|}{$\begin{array}{l}\text { GRUPO I } \\
\text { NÓS, VÓS }\end{array}$} & \multicolumn{6}{|c|}{$\begin{array}{c}\text { Grupos II, III E IV } \\
\text { NÓS E NOSOUTROS, VÓS E VOSOUTROS }\end{array}$} & \multicolumn{3}{|c|}{$\begin{array}{c}\text { Grupo V } \\
\text { NOSOUTROS, VOSOUTROS }\end{array}$} \\
\hline OBRAS & nom. & comp. & OBRAS & \multicolumn{2}{|c|}{$\begin{array}{l}\text { nominativo } \\
\text { simple comp. }\end{array}$} & \multicolumn{2}{|c|}{$\begin{array}{l}\text { complemento } \\
\text { simple comp. }\end{array}$} & $\%$ simple & OBRAS & \multirow[t]{2}{*}{ nom. } & comp. \\
\hline TQ1-20 & 2 & & FP1-38 & 2 & 1 & 6 & & \multirow{4}{*}{90,00} & ABF1-12 & & 1 \\
\hline TQ2-20 & 8 & 2 & FP2-sd & & 1 & 6 & & & PBS-23 & 2 & \\
\hline APP-22 & 2 & 8 & FP3-sd & & & 3 & & & NPD1-26-28 & 1 & \\
\hline CPCh-37 & 4 & 3 & FP5-sd & & & 1 & & & DGM-36 & & 1 \\
\hline AC-13 & 3 & 1 & CFRA-13 & 5 & & 3 & 1 & 88,89 & MV3-46 & & 1 \\
\hline RPV-05 & 3 & & DAS1-36 & 2 & & & & \multirow{3}{*}{88,89} & & & \\
\hline CCBM-13 & 2 & 1 & DAS2-36 & 3 & 1 & & & & & & \\
\hline TP1-36 & 2 & 1 & DAS3-36 & 3 & & & & & & & \\
\hline DLCG-20 & & 2 & AC2-46 & 1 & & 2 & 1 & 75,00 & & & \\
\hline RM-44 & & 2 & VT2-40 & 2 & \multirow[t]{2}{*}{1} & & 1 & \multirow{6}{*}{71,43} & & & \\
\hline OPG[RV]-37 & 1 & 1 & VT3-42 & 1 & & & 1 & & & & \\
\hline OPG $[\mathrm{GF}]-37$ & 1 & & VT4-43 & & 1 & 1 & & & & & \\
\hline FA2-44 & 1 & & VT5-45 & 3 & & 1 & & & & & \\
\hline LSSA-08 & 1 & & VT6-46 & & & 1 & & & & & \\
\hline TC-36 & & 1 & VT7-46 & & & 1 & & & & & \\
\hline & & & PB1-23 & & 1 & 2 & & 66,67 & & & \\
\hline & & & MPA2-13 & 4 & 2 & 5 & 2 & 6316 & & & \\
\hline & & & MPA6-20 & 2 & 2 & 2 & 1 & 03,10 & & & \\
\hline & & & PC-36 & 4 & & 5 & 6 & 60,00 & & & \\
\hline & & & PG-10 & 9 & 8 & 5 & 2 & 58,33 & & & \\
\hline & & & JMP1-43 & & & & 1 & & & & \\
\hline & & & JMP3-45 & & & 1 & & 57,14 & & & \\
\hline & & & JMP4-46 & 1 & 2 & 2 & & & & & \\
\hline & & & DDF-20 & 1 & 1 & & & 50,00 & & & \\
\hline & & & CR-12 & & 6 & 7 & & 46,15 & & & \\
\hline & & & OSP1-40 & & 1 & 2 & 2 & 40,00 & & & \\
\hline & & & DE1-07 & 1 & 1 & & & 33,33 & & & \\
\hline & & & DE2-07 & & 1 & & & & & & \\
\hline
\end{tabular}

Táboa 9: Presenza relativa das formas simples e compostas en Papés 
Como se pode apreciar, hai textos de ambiente compostelán en todo o arco, mostrando, na nosa opinión, que ámbalas solucións estaban moi vizosas nas variedades diatópicas da comarca e que foron outros os factores que determinaron a escolla. Vistos os datos actuais (Álvarez 2010), non sorprende nin a escolla de nós por autores que, mesmo participando da vida compostelá, se sitúan máis ao S ou SW (p. ex., APP-22 e CPCh-37) nin a opción mindoniense de N. P. Díaz. Si chama a nosa atención a alta frecuencia que tińa aínda a forma composta na variedade pontevedresa de Pintos e o testemuño inequívoco do ourensán Pedro Boado; e, en contrapartida, a forte presenza da forma simple en textos e autores próximos a rexións que hoxe seleccionan adoito nosoutros e vosoutros como variantes non marcadas (Gómez de Ferrol, Florencio Pol, Alberto Camino, Fernández Neira, Pardo de Andrade...).

2. As formas compostas nosoutros e vosoutros alcanzan a proporción máis alta no nominativo, con preto dun terzo do total de formas empregadas (nosoutros + vosoutros, 30,17\% / nós + vós 69,83\%). A tendencia á especialización funcional entre as dúas variantes, con preferencia da forma composta no suxeito e da forma simple tras preposición, foi observada como un feito de variación diatópica nas derradeiras décadas do século XX (Álvarez 2010; con maior desenvolvemento en Álvarez 1998: 25-35), polo que resulta interesante comprobar ata que punto esta reasignación de funcións se daba xa na época que estudamos e se tiña protagonistas destacados entre os nosos autores.

O compostelán que asina CR-12 é un claro modelo desta especialización, con seis rexistros de nosoutros como forma do nominativo (5 sux., 1 atr.) e outros sete de nós como complemento ( 6 tras preposición, 1 en sintagma comparativo); tamén o é o autor de PB1-23, como se pode advertir nos tres rexistros que ofrece (vosoutros sux. / ai de vós, tras vós). Outros parecen apuntar con menor rotundidade á mesma tendencia, en distintos graos: Florencio Pol usa nosoutros na metade das ocorrencias como suxeito (2 nós, 2 nosoutros), pero como caso complemento emprega sempre formas simples (10 nós, 6 vós); nalgúns textos obsérvase a forma composta no suxeito, soa ou en concorrencia coa simple, pero non hai rexistros de ningunha variante con outras funcións (DE1-07 e DE2-07 [1 simple / 2 composta], DDF-20 [1/1], PBS-23 [0/2], NPD1-26-28 [0/1], DAS2-36 [3/1]). 
Con todo, son varios os autores que contradín coa súa práctica a existencia dunha regra universal nese sentido. Testemuñan formas simples e compostas, tanto no nominativo coma no complemento, Pintos (nom. simple / nom. composta / compl. simple / compl. composta: 1/3/2/1), Turnes (6/4/2/2), Pardo de Andrade (6/7/4/3), Fernández Magariños (7/2/2/2) e Fernández Neira (9/5/8/2). Presentan cadanseu rexistro de formas compostas só como complemento Fandiño (ABF1-12), CFRA-13, DGM-36, Camino (AC2-46) e Valladares (MV3-46). Pero, sobre todo, cómpre salientar o anónimo de Cacheiras, que emprega só formas simples como suxeito (3 nós, 1 vós), reparte os complementos con preposición entre as formas simples (5) e as compostas (2), e escolle sempre vosoutros no segundo termo da comparación (4).

Esta obxección non invalida a conclusión anterior sobre a especialización funcional. Ao noso xuízo confirma a variación gramatical, pois en distintos autores - e en distintas variedades sociais ou territoriais - a escolla entre nós e nosoutros se guiaba, entón coma agora, por criterios diferentes.

3. Nestes textos non hai apenas datos en que comprobar se a conveniencia de expresar o xénero guía a escolla das formas compostas — como suxire Saco (1868: $57)^{21}$, que puido percibir este trazo noutras variedades diatópicas_- pero os indicios que recollemos no noso corpus non apuntan nesa dirección. Non abonda con localizar exemplos en que nosoutros e vosoutros se refiran a un grupo marcado como masculino (p. ex., "Eu ben sei q[u]e á muller ten alma, entendem[en] to memoria voluntâ é sentidos como nosoutros", PC-36: 696). O determinante é que nunca se rexistran nosoutras e vosoutras, e nos contados casos en que o grupo é feminino emprégase a forma simple:

Ás miñas curmans. Moito decirvos quixera se á míña sanguinidá que á vos tan chegada está un freno non me puxera (FP3-sd: 4).

¡Malpocadas meniñas! [...] para da-l' o tal vez á un falso amante, que con falsos cariños vo-l' o estrague, cal vos os pajariños! (FA2-45: 143).

21 "De las dos clases de formas plurales nos, vos, nosoutros, vosoutros, las primeras nos, vos, idénticas a las latinas, son las que se usan de ordinario: las segundas, formadas por composición (nos-outros, vos-outros) se emplean principalmente cuando se quiere hacer resaltar la diferencia de género" (Saco 1868: 57). 
4. En cambio, si parece ser determinante o carácter contrastivo que aínda hoxe se comproba en falantes maiores de gran parte do territorio galego: nosoutros e vosoutros son formas marcadas, fronte ás simples correspondentes, porque chaman a atención sobre a delimitación do grupo por un trazo que comparten os seus membros, e en consecuencia exclúen tódolos individuos que están fóra desa comunidade. Non podemos afirmar sen marxe de dúbida que este trazo motivase a escolla en tódalas ocorrencias do noso corpus nin que os distintos autores fosen conscientes desta característica do sistema, pero si que estas formas compostas se poden interpretar recorrentemente como contrastivas. Estes son só algúns exemplos:

Non falemos de eso, Diego, porque mais temos nosoutros con que dar na cara á ingratos, que oxe votan por vosoutros; cando foi do Diputado alguns do partido noso foron sacados da cama a maneira do raposo ['os do meu partido / os do teu partido'] (VT-40: 70, 72). mais dixso para consigo, tamen vosoutros abendes de boar para ó inferno ['os gabachos, os nosos inimigos'] (PG-10: 333).

Estes negrumantes, estes farouteiros, cuidan que nosoutros c'os ollos non vemos, que non descubrimos, que non conocemos, que non tras da moza, mais dos seus arreos, veñen estes demos galans calaceiros? ['os da nosa aldea, fronte aos señoritos de lonxe e os seus recadeiros'] (JMP4-46: 63).

Eu ben sei que á muller ten alma, entendemento memoria voluntâ é sentidos como nosoutros ['os homes, aos que está contrapondo a muller'] (PC-36: 696).

\subsection{Vós como forma de tratamento cortés}

Como forma de cortesía emprégase sempre vós (39 rexistros como P2 ${ }^{22}$ ), nunca vosoutros. Este é un uso amplamente representado no corpus, sobre todo en textos composteláns; débese ter presente que foi precisamente no occidente da Coruña, entre Santiago e a costa occidental, onde permaneceu máis vivo ata os nosos días ${ }^{23}$.

${ }^{22}$ Limitamos a análise ao uso das formas pronominais tónicas, que nos interesa por complementariedade ou contraste co exposto neste apartado. Non nos detemos noutras marcas que testemuñan este tratamento, como a concordancia do verbo ou o uso de clíticos.

23 Así describiamos a situación ao inicio do derradeiro cuartel do século XX, a partir do traballo de campo realizado entre 1974-1980: "Este uso de vós como forma de tratamento segue vivo na lingua falada 
A decadencia de vós como forma de cortesía é antiga e arrinca dun cambio nos usos sociais, en certo modo inducido desde as instancias de poder, que excede o ámbito do galego (Cintra 1972). Ora ben, vós presenta o problema de que só marca adecuadamente a distancia cando o alocutario é singular, pois se é plural conflúe coa forma non cortés; de feito, no noso inventario clasificamos como 'segunda persoa de plural non cortés' tódalas formas vós con referente plural ao carecermos de elementos para procedermos doutro xeito (aínda así vós sg. acada o 45,35\% das formas pronominais tónicas de cortesía). Non descartamos que o uso de vosoutros fronte a vós pl. tivese algún sostén na vixencia de vós sg. como forma cortés (vós 'cerimonia' [P2, P5] I ti [P2] e vosoutros (vós) [P5] 'non cerimonia'); se así fose, o esmorecemento de vós sg. arrastraría consigo a suposta maior conveniencia de vosoutros no plural ${ }^{24}$.

Non é o noso propósito tratar neste lugar as distintas formas e fórmulas de tratamento cortés presentes en Papés, a pesar de considerarmos que este é tamén un trazo de grande interese para a caracterización lingüística dos textos e os seus autores. $\mathrm{Na}$

actualmente na parte occidental da provincia da Coruña. Sabemos da súa existencia en aldeas próximas ó Son (Baroña e outras), en Baio e zona de influencia, na Picota (Mazaricos), nos Ánxeles [Brión], en Páramos [Val do Dubra] (máis frecuente nas aldeas próximas, como Quintáns e A Cavada), en Carnota e aldeas veciñas, en Marzoa (Oroso) e en puntos da Mahía. É un tratamento dirixido a vecińos e familiares que por edade merecen un respeto ou consideración especial; aplícase de fillos a pais, de netos a abós, de novos a vellos... pro non ó contrario. Na Picota recollémo-lo testemuño dun home duns sesenta anos [nacido por volta de 1920] que o usa sempre referíndose ós "patróns" ['persoas maiores desde a súa óptica’], pro non coa xente da súa edade, de non ser que merezan unha consideración especial por razóns doutro tipo; é decir, a forma usté non suplantou totalmente a vós, senón que reduciu o seu campo de aplicación, establecendo distintos grados de respectuosidade. [...] este modelo está abocado á desaparición (en Páramos, p. ex., trataban de agachalo, intentando atribuírllelo, en exclusiva, ós das aldeas próximas: "na carretera non se di") (Álvarez 1980: 156-158).

${ }^{24}$ Non temos rexistros galegos do vós sg. entre iguais nin do usado con inferiores, ben testemuñados en espańol (Lapesa 1970: 149ss), pois en Galicia sempre é de respecto, mesmo dun respecto superior ao mostrado polas variantes de vostede, que poden concorrer nos mesmos falantes (especialmente o cast. usté). Tamén está ben testemuñado en español o vos sg. respectuoso entre 1650 e 1800, mais, aínda que "no es fácil determinar hasta cuándo refleja una realidad efectiva del habla y cuándo empieza a ser convencionalismo arcaizante [...]. A fines del siglo XVIII debía de estar consumada la desaparición del vos respetuoso en el coloquio ciudadano de España" (Lapesa 1970: 151). A queda do uso de vós sg. de respecto tamén se produciu en portugués durante ese século: "É no século XVIII que este último resíduo da apóstrofe directa mas cortês, herdada do latim, num momento que me parece situar-se nos meados do século, e portanto na passagem do reinado de D. João V [1706-1750] para o de D. José I, cai em desuso (ou se torna traço arcaizante e um tanto ridículo da fala de pessoas velhas ou provincianas), ficando o campo dos tratamentos de cortesia completamente entregue ao domínio das formas nominais e da $3^{\text {a }}$ pessoa verbal" (Cintra 1972: 34). 
Táboa 10 achegamos só os datos precisos para podermos facer o contraste entre as variantes de vostede \{vosté, voste, v[o]stè, vusté, boste, bosté, uste, vosted', vostede, bostede, bustede; vostedes, vostés\}, con fórmulas que implican concordancia en P3 ou P6, e vós (P5). A táboa mostra que, en lińas xerais, a opción vai a un ou outro aparato formulario, cunha secuencia cronolóxica bastante ben marcada ${ }^{25}$ : forman o Grupo I os oito textos que sempre presentan vós, case todos das primeiras décadas do período considerado; no Grupo III, os sete textos que sempre presentan vostede, case todos da segunda parte do período. Entre ambos, no Grupo II, obras do último treito en que hai oscilación: a única que varía internamente é PC-36, con clara preferencia da fórmula máis conservadora; o suposto autor común de DAS-36 só usa vós no primeiro dos tres diálogos; compórtase do mesmo xeito o autor anónimo de TP-36; canto a Florencio Pol, só emprega vostede na única obra que temos datada.

\begin{tabular}{|c|c|c|c|c|c|c|c|c|c|c|}
\hline \multicolumn{3}{|c|}{$\begin{array}{c}\text { Grupo I } \\
\text { vós }\end{array}$} & \multicolumn{5}{|c|}{$\begin{array}{l}\text { Grupo II } \\
\text { vós, vostede }\end{array}$} & \multicolumn{3}{|c|}{$\begin{array}{l}\text { Grupo III } \\
\text { vostede }\end{array}$} \\
\hline \multirow{2}{*}{ OBRA } & \multirow{2}{*}{ NOM. } & \multirow{2}{*}{ COMPL. } & \multirow{2}{*}{ OBRA } & \multicolumn{2}{|c|}{ vós } & \multicolumn{2}{|c|}{ vostede } & \multirow{2}{*}{ OBRA } & \multirow{2}{*}{ NOM. } & \multirow{2}{*}{ COMPL. } \\
\hline & & & & NOM. & COMPL. & NOM. & COMPL. & & & \\
\hline DE2-07 & 9 & 2 & DAS1-36 & 1 & & & & AC-12 & 2 & 2 \\
\hline CFRA-13 & 13 & 3 & DAS2-36 & & & 1 & & CLB-33 & 5 & 2 \\
\hline CCBM-13 & 4 & & DAS3-36 & & & 2 & & TC-36 & 2 & 1 \\
\hline MPA2-13 & 1 & & PC-36 & 3 & 2 & 1 & & OPG $[\mathrm{GF}]-37$ & 3 & 1 \\
\hline TQ1-20 & 2 & & TP1-36 & 1 & & & & C1836-43 & 8 & \\
\hline TQ2-20 & 1 & & TP2-36 & & & 8 & 4 & JMT-44 & 2 & \\
\hline APP-22 & 2 & 1 & FP1-38 & & & & 1 & CCX-46 & 1 & \\
\hline VT5-45 & 1 & & FP3-sd & & 1 & & & & & \\
\hline & & & FP5-sd & & 2 & & & & & \\
\hline
\end{tabular}

Táboa 10: Presenza relativa de vós e vostede(s), como formas de respecto, en Papés

Así pois, os nosos textos, ademais de caracterizaren a lingua dos distintos autores pola súa práctica cortés, testemuñan un proceso de cambio e permiten datar

25 Tódolos rexistros de vós cortés identificados e computados na Táboa 10 teñen referente singular, polas razóns expostas máis arriba. En cambio, con vostede e variantes, contabilízanse as formas de singular e plural, o que pode producir unha distorsión os datos que debe terse en conta. As formas de plural rexistradas son as seguintes: vostedes (DAS3-36, TQ2-36 [3r], JMT-44), vostés (TQ2-36). 
unha mudanza nos hábitos sociais e o abandono regular de vós sg. como forma de cortesía popular por volta da fin do primeiro cuartel do séc. XIX. Prodúcese esta, con algún atraso, no ronsel da datada por Cintra a mediados do séc. XVIII para o portugués e da apuntada por Lapesa para o español de España por volta de 1800 (cf. supra, nota 24).

\section{6. $A L A ́$ E $A L O ́$}

Seleccionamos tamén como obxecto de análise a opción entre acá e acó, alá e aló, porque a cartografía actual destas variantes (Mapa 5) mostra que están sometidas a procesos de cambio lingüístico de longa data, que tratamos por extenso noutros lugares e tentaremos resumir a seguir.

No galego actual, na lingua espontánea, as formas en -ó só existen cun grao suficiente de normalidade ao norte dunha liña que vai da Costa da Morte á serra Segundeira (Zamora); cómpre advertir de que nese territorio, con maior ou menor incidencia, tamén existe alá. Santiago de Compostela e a súa comarca sitúanse ao sur desa liña, próximas, mais na parte de Galicia onde non se emprega aló. Tódolos datos do galego falado que obtivemos por distintos medios nas catro últimas décadas apuntan no mesmo sentido (Álvarez/Xove 2008a).

Hai información histórica abonda para podermos afirmar, sen xénero de dúbida, que noutrora estas formas ocuparon tamén o sur do territorio (Álvarez/ Xove 2008b). Neste repregamento cara ao norte e leste, as formas en -ó deixan bandas de maior ou menor incidencia: un gran territorio suroccidental en que aló se descońece (área A no Mapa 5), con só algún que outro rexistro testemuñal en falantes excepcionais e puntos illados; unha banda de incidencia baixa ou media (área C), sen rexistros constantes pero recorrentes; e, ao norte da lińa mencionada, un territorio en que aló é forma única ou ten unha incidencia altísima fronte á concorrente alá (área B) (Álvarez/Xove 2008a). O concello de Santiago de Compostela e a súa contorna suroccidental están no territorio abandonado por aló; en cambio, os concellos da contorna nororiental atópanse na banda de transición mencionada (área C).

Tamén se observa unha difusión ao longo do eixe atlántico, de xeito que na lińa Ferrol-Tui se vai instalando de xeito exclusivo a forma en $-a ́$. Nese corredor atópase Santiago de Compostela, xunto coa maior parte dos centros de produ- 
ción destes textos. Nos espazos urbanos nótase, ademais, en toda Galicia, a presión do castelán, que favorece $-a ́$ como forma non diferencial.

Esta é a situación que se deseña con datos das derradeiras décadas do século XX. Neste contexto, a análise deste trazo en Papés revélase importante non só para o mellor cońecemento destes textos e a súa variación interna, con vistas a algúns dos obxectivos declarados, senón tamén para o estudo dos procesos de cambio históricos en galego e para a historia da configuración do modelo lingüístico do galego culto. Nos textos que nos ocupan non hai progresión dunha forma ou outra ao longo do tempo, pero si un tratamento diferenciado en obras e/ou autores.

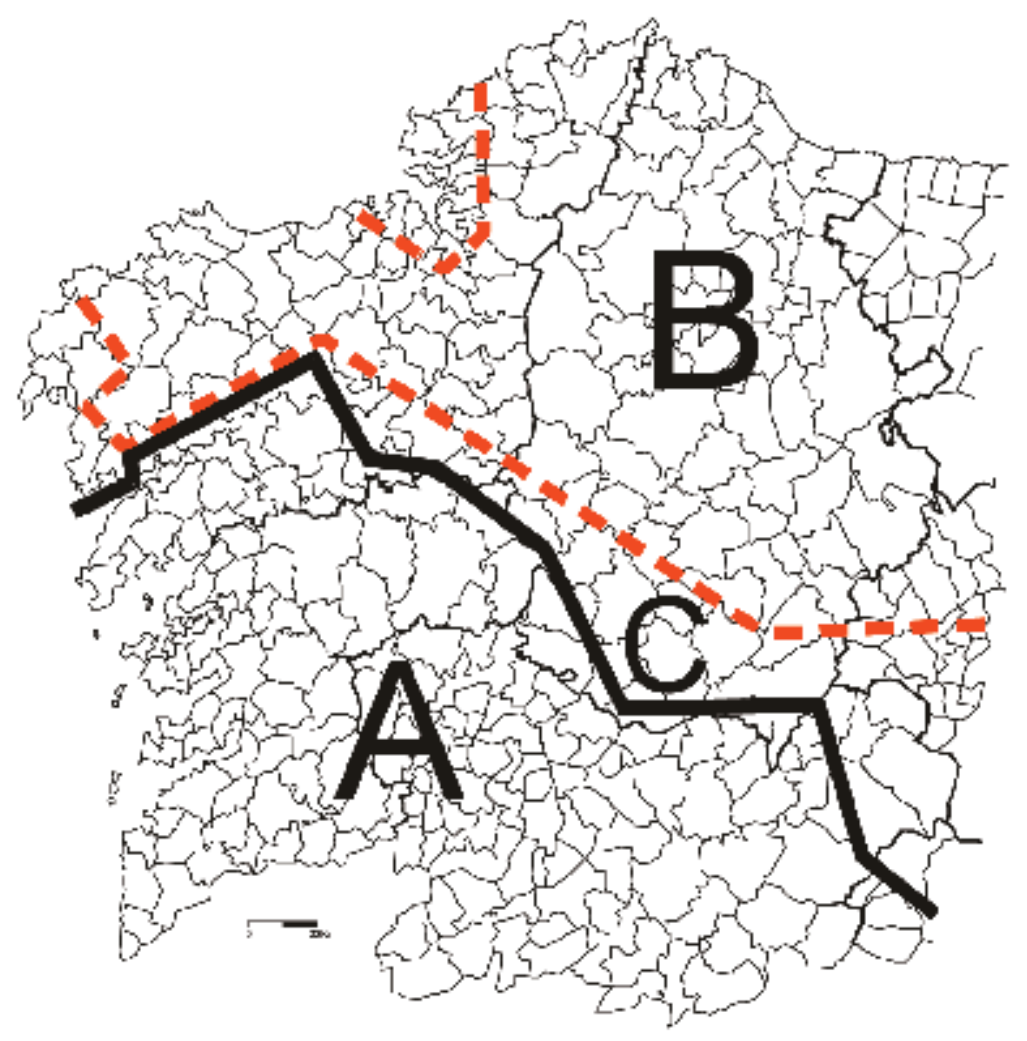

Mapa 5: Distribución territorial de alá e aló. Fonte: Álvarez/Xove 2008a 


\begin{tabular}{|c|c|c|c|c|c|c|c|}
\hline \multicolumn{2}{|c|}{$\begin{array}{l}\text { GRUPO I } \\
\text { SEMPRE }-A\end{array}$} & \multicolumn{4}{|c|}{$\begin{array}{l}\text { GRUPOS II, III E IV } \\
\text { VARIACIÓN }-\hat{A},-O ́\end{array}$} & \multicolumn{2}{|c|}{$\begin{array}{l}\text { GRUPO V } \\
\text { SEMPRE -Ó }\end{array}$} \\
\hline$a c a ́$ & alá & $a c a ́$ & alá & acó & aló & acó & aló \\
\hline & LSSA-08 & DE1-07 & DE1-07 (2) & & & & $\begin{array}{l}\text { CFRA-13 } \\
\text { (2) }\end{array}$ \\
\hline \multirow[t]{3}{*}{ PG-10 (8) } & PG-10 (12) & DE2-07 & DE2-07 (3) & & DE2-07 & CCBM-13 & $\begin{array}{l}\text { CCBM-13 } \\
\text { (3) }\end{array}$ \\
\hline & ABF1-12 (2) & TQ1-20 & & & TQ1-20 (2) & CLB-33 & CLB-33 (4) \\
\hline & CR-12 (2) & & TQ2-20 (2) & & & & DGM-36 \\
\hline \multirow[t]{3}{*}{ DDF-20 } & DDF-20 & & TP1-36 & & & & $\begin{array}{l}\text { C1836-43 } \\
(7)\end{array}$ \\
\hline & PBS-23 & $\mathrm{TP} 2-36$ & TP2-36 & & TP2-36 & CCX-46 (5) & CCX-46 (4) \\
\hline & NPD2-28 & MPA2-13 & MPA2-13 (2) & & MPA2-13 & & \\
\hline PC-36 (7) & PC-36 (6) & & & & MPA5-14 & & \\
\hline CPCh-37 & CPCh-37 (3) & MPA6-20 & & & MPA6-20 (2) & & \\
\hline \multirow[t]{4}{*}{$\begin{array}{c}\mathrm{OPG}[\mathrm{RV}]-37 \\
\text { (2) }\end{array}$} & $\begin{array}{c}\text { OPG }[R V]-37 \\
\text { (8) }\end{array}$ & APP-22 & & & APP-22 & & \\
\hline & RM-44 & PB2-23 & & PB2-23 & & & \\
\hline & JMP3-45 (2) & VT1-29 & VT1-29 & & & & \\
\hline & JMP4-46 & & VT3-42 (2) & & VT3-42 (3) & & \\
\hline MV2-45 & MV2-45 (2) & & & & VT5-45 & & \\
\hline \multirow[t]{10}{*}{ MV3-46 } & MV3-46 (2) & & & DAS1-36 (3) & DAS1-36 (4) & & \\
\hline & & DAS2-36 & & DAS2-36 & DAS2-36 (2) & & \\
\hline & & & & DAS3-36 & & & \\
\hline & & & $\mathrm{OPG}[\mathrm{GF}]-37$ & OPG $[\mathrm{GF}]-37$ & OPG $[\mathrm{GF}]-37$ (6) & & \\
\hline & & FP1-38 & & FP1-38 (4) & FP1-38 (6) & & \\
\hline & & & & & FP2-sd (3) & & \\
\hline & & & & & FP3-sd (2) & & \\
\hline & & & JMT-44 & JMT-44 (2) & JMT-44 (3) & & \\
\hline & & & & & AC1-45 & & \\
\hline & & & AC2-46 & & $\mathrm{AC} 2-46$ & & \\
\hline
\end{tabular}

Táboa 11: Presenza relativa de acá e acó, alá e aló en Papés ${ }^{26}$

Algúns deles nunca empregan formas en -ó (Grupo I). Como era de esperar, non as usan o pontevedrés Juan Manuel Pintos, o estradense Marcial Valladares, o noiés Ramón Malvárez (RM-44r), o dezao Ramón Varela Vahamonde (OPG[RV]-37) nin o ourensán Pedro Boado. En cambio, sorprende que escolla sempre -á Fernández Neira — cun número tan alto de rexistros que non ofrece dúbida-, pois non podía descoñecer as formas acó e aló, que tiñan que ser habituais na bisbarra da Coruña e non puideron pasar desapercibidas noutros lugares

\footnotetext{
${ }^{26}$ Só indicamos o número de rexistros cando non son formas únicas.
} 
ao fino sentido dun autor tan atento á incorporación de variantes dialectais. ¿El será que Neira as omite por razóns de prestixio?, ¿ou simplemente sacrifica o diferencialismo en aras da comprensión ${ }^{27}$ ? En calquera caso, hai nel unha escolla consciente, feita en contra da forma que, sobre ser diferencial respecto do castelán, é a que corresponde á súa presunta variedade lingüística de orixe. Tamén se inclina por acá e alá Antonio Benito Fandiño, compostelán a tódolos efectos, aínda que tampouco podía descońecer as formas en -ó habituais na aldea da súa familia (Albixoi-Mesía), coa que seguiu mantendo contacto toda a vida; proba de que non a descońece é que forma parte dunha cántiga que introduce nun artigo en castelán no Heráclito, xornal do que era fundador, director e único redactor: "Aló arriba no monte, / habia non sey que santo, / quen lle rezar non sey qué, / ganará non sey que tanto." (Papés: 577). En principio pode sorprender tamén que o único rexistro do vivariense Nicomedes Pastor Díaz sexa de alá, pois aínda hoxe os falantes mindonienses se identifican plenamente coa outra variante; consignemos o dato sen tirarmos conclusións, pois pode ser casual que só quedase rexistrada a forma secundaria na área.

Seguindo cos autores identificados, tódolos que empregan acó e aló proceden do norte de Galicia ou están dalgún xeito en estreito contacto con esas terras; ora ben, ningún deles usa sempre formas en -ó, testemuñando coa súa práctica a variación do tipo $\{a l o ́$, alá\} que, como dixemos, se dá no amplo territorio marcado como B e C no mapa. Mostran clara preferencia por -ó (Grupo IV), Florencio Pol (de Ordes, 1 acá / 4 acó e 11 aló) e mailo autor da versión OPG[GF]-37 (1 alá / 1 acó, 6 aló, que pola cadea onomástica da atribución, Juan Gómez del Ferrol, cabería vincular á comarca ferroláa ${ }^{28}$; repárese en que neste trazo se separa da versión que chamamos OPG[RV]-37); son tamén as preferidas por Juan Montero [Telinge] (JMT-44: 1 alá / 2 acó e 3 aló), nacido en Santiago, con conexións familiares en Lugo e actividade profesional na Co-

${ }^{27}$ Lembremos unha vez máis a súa advertencia lingüística no inicio: "La diversidad que se observa en la pronunciacion y significacion de términos en cada una de las siete Provincias del Reyno de Galicia, me ha precisado á omitir muchos, que ciertamente no se entenderian, y solo me valí de aquellos mas claros aunque del país, á fin de que con la mayor facilidad puedan todos comprender su lectura." (Papés: 55).

${ }^{28}$ Non atopamos datos biográficos nin outras informacións da súa existencia real. Couceiro Freijomil limítase a recoller a súa pegada literaria: "Es autor de la poesía humorística O Pleiteante, muy celebrada. Se inserta en el Álbum de la Caridad." (Couceiro 1952: s.v). 
ruña ${ }^{29}$, e en menor medida por Alberto Camino ( 1 alá / 2 aló), que se despraza de Ferrol á Coruña e Santiago. As dúas solucións aparecen equilibradas (Grupo III) no mariñán Manuel Pardo de Andrade, de Oleiros, con conexións familiares nunha alargada área coruñesa dentro do dominio de aló ( 2 acá e 2 alá / 4 aló), e no compostelán Vicente Turnes (1 acá, 3 alá / 4 aló $)^{30}$.

- Ata agora, os distintos autores foron confirmando bastante ben as nosas

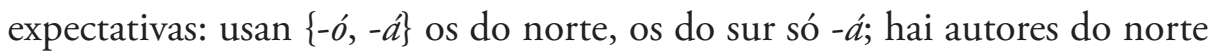
que optan pola forma xeral $-a \dot{a}$; non hai autores do sur que opten pola forma diferencial -ó. Neste contexto, ¿que práctica lingüística mostran os autores anóminos e que conclusións podemos tirar dela?

- Escolle sempre -á (Grupo I), cunha cantidade de rexistros que non deixa marxe de dúbida, o crego carlista autor de PC-36 (7 acá / 6 alá); tamén o autor de CPCh-37 (1 acá, 3 alá), nas proximidades da vila de Noia, que Barreiro suxire identificar con Ramón Malvárez (Papés: 401), que como vimos ten a mesma práctica. A eles súmanse, ben que con menor número de rexistros, que non eliminan a intervención do azar, outros tres: o autor absolutamente descońecido e ilocalizable de LSSA-08 (1 alá); o de CR-12 (2 alá), que asina con pseudónimo en Combarro [lugar do CastiñeiriñoSantiago]; e o de DDF-20 (1 acá, 1 alá), tamén saído do ambiente liberal compostelán.

- Por contra, outros anónimos só usan formas en -ó (Grupo V). Así o fai quen asina como F.R.A. (CFRA-13: 2 aló) e como F.R. (CCBM-13: 1 acó, 2 aló), confirmando o mesmo uso e avalando cun novo dato a hipótese da autoría única. Tamén o remitente de CLB-33 a un periódico de Madrid, que é ou simula ser de Betanzos (1 acó, 5 aló); o autor de DGM-36 (1 aló), escrito e publicado na Coruña; o de C1836-43 (7 aló), que di concluír en "Madrid 16 de Nre de 1843"; e mailo de CCX-46 (5 acó, 4 aló), residente na Coruña,

29 Barreiro Fernández, Xosé Ramón (coord.) (2003): Parlamentarios de Galicia. Biografias de deputados e senadores (1810-2003). 2a ed. corrixida e aumentada. Santiago de Compostela: Parlamento de Galicia / Real Academia Galega.

${ }^{30}$ Está por facer a biografía de Turnes (Santiago 1786-1865), que viviu entre a casa de Santiago e a de Oza (Teo) (De la Iglesia 1861:169). Axudaría sabermos onde tińan os seus vencellos familiares os Turnes, apelido que se concentra no occidente coruñés, co epicentro nos concellos da Baña e Santa Comba, onde ademais se localiza o único topónimo Turnes (Bazar-Santa Comba). Os Río Maldonado proceden da Casa de Poulo (Ordes), desde onde se trasladan a Santiago no século XVIII. 
que usa significativamente como pseudónimo Cristobo de Xallas. Todos eles deben ser autores con instalación ou forte conexión coa metade norte de Galicia, a partir da lińa debuxada no Mapa 5.

- Os demais mostran mestura de formas, como vimos fan adoito os autores das variedades do norte, con distintos graos de preferencia. En DE-07 (Grupo II: 2 acá, 5 alá / 1 aló) a presenza de -ó é ocasional, do mesmo xeito que o é -á en DAS-36 (Grupo IV: 1 acá / 5 acó, 6 aló); corresponden a dúas variedades distintas, coa presenza testemunal dunha ou outra variante minoritaria, que ben poden situarse no gradiente dunha área fronteiriza. A preferencia de -á existe tamén, de forma menos contundente (Grupo II), en TQ-20 (1 acá, 2 alá / 2 aló) e en TP-36 (1 acá, 3 alá / 1 aló); as dúas opcións equilíbranse en APP-22 e PB2-23 (Grupo III).

O estudo deste trazo confirma o carácter fronteirizo de Santiago de Compostela, desde o lado sur da isoglosa, xa na altura da composición destes textos, unha situación moi similar á actual. Dános tamén unha característica que debemos buscar nos posibles autores dos diálogos anónimos: a maior/ menor presenza de acó e aló desprázanos en dirección NE/SWpola xeografía de Galicia.

Seguimos sen saber quen foi o autor anómino de CCBM-13, agochado baixo as siglas F.R., posiblemente o mesmo que edita CFRA-13, baixo as siglas F.R.A. Comparten o uso de acó e aló, nos dous textos sen testemuńos concorrentes de -á; non é a exclusividade o que máis chama a nosa atención, pois seguramente cunha maior cantidade de texto o autor, coma outros coterráneos, usaría ámbalas opcións. O uso de -ó oriéntanos cara a un autor que proceda da parte norte de Galicia ou que, sendo compostelán, teña conexións biográficas con ese territorio ou na contorna NE. Isto avalaría a atribución a un Rúa Figueroa (Antonio ou Manuel $)^{31}$ —ata agora baseada na similitude das siglas e nun rumor de que se fai eco Carré (Carvalho 1984)—, santiagués, de familia oriúnda da banda de Arzúa e Vilasantar (seguindo a Pérez Constanti: 294); tamén podería apoiar a de

31 Antonio Rúa Figueroa faleceu en 1819, polo que podería ser autor de CFRA-13 e CCBM-13, pero non das tertulias da Quintana (1820), de Picaños (1836) e da Alameda (1836), involucradas na argumentación de Carballo e Carré (Carballo, “Diálogos gallegos...”, 15 e nota 5). Véxase tamén Carvalho 1984. 
Manuel Pardo de Andrade, que apunta Odriozola (1983, apud Carvalho 1984: 726); non desbota por completo, pero engádelle un punto de dificultade, a hipótese de que se trate de Juan Bautista Caamiña, santiagués oriúndo de Cerdedo, director da Gazeta (suxerida por Barreiro, en Papés: 135-136); si anula, ao noso entender, a atribución a Manuel Acuña Malvar (Salcedo-Pontevedra 1757), sostida por Isidoro Millán e apoiada por Álvarez Blázquez.

\section{PODEREMOS TRAZAR UN PERFIL LINGÜÍSTICO E PÓRLLES NOME A ESTES AUTORES?}

Ao longo da nosa exposición, trazo a trazo, con base nas formas empregadas e a frecuencia relativa, fomos anunciando conclusións parciais, debuxando liñas para uns posibles perfís dos autores anónimos, apoiando ou rebatendo algunhas atribucións ou identificacións... Cremos ter mostrado, nos sucesivos comentarios, que o método de análise é válido para este obxectivo, toda vez que, na maior parte dos casos, os autores coñecidos mostran prácticas lingüísticas congruentes co que se espera deles á luz do coñecemento da variación diatópica sincrónica e diacrónica. Nos distintos lugares salientamos, ademais, as diverxencias comprobadas nalgúns destes autores identificados, que ou ben anuncian unha práctica de abandono de trazos diatópicos á procura dun modelo de galego culto menos connotado ou menos local, ou ben reclaman unha revisión sobre o noso coñecemento acerca da extensión e vixencia dalgúns trazos dialectais naquela altura.

A pesar dos avances notables producidos nos últimos anos, son aínda moitos os autores anónimos que agardan a que os investigadores desvelemos os seus nomes e lles devolvamos o protagonismo na historia da lingua e literatura galegas e mais na construción do galego moderno. En síntese, estas son as semellanzas e diferenzas a partir dos trazos analizados por nós nesta contribución: 


\begin{tabular}{|c|c|c|c|c|c|c|c|c|}
\hline & $\$ 2.1$ & $\$ 2.2$ & $\$ 3.1$ & $\$ 3.2$ & $\$ 4$ & $\$ 5.1$ & $\$ 5.2$ & $\$ 6$ \\
\hline & non + v. & $\begin{array}{c}\text { non }+ \\
\text { acu }\end{array}$ & lles = lle & llelo $=11 \mathrm{o}$ & nadia... & $\begin{array}{c}\text { no- } \\
\text { soutros }\end{array}$ & vós P2 & aló, alá \\
\hline OAS-01 & $\mathrm{V}$ & - & IV & - & - & - & - & - \\
\hline RVP-05 & - & V & IV & - & - & I & - & - \\
\hline DE-07 & IV & $\mathrm{V}$ & IV & - & I & IV & I & II \\
\hline LSSA-08 & I & - & - & - & - & I & - & I \\
\hline AC-12 & V & V & III & I & I & - & III & - \\
\hline CR-12 & V & $\mathrm{V}$ & V & - & - & III & - & I \\
\hline AC-13 & V & - & - & - & - & I & - & - \\
\hline CCBM-13 & V & - & III & - & - & I & I & V \\
\hline CFRA-13 & V & IV & - & I & I & II & I & $\mathrm{V}$ \\
\hline DLCG-20 & - & - & - & - & - & I & - & - \\
\hline DDF-20 & V & I & II & - & - & III & - & I \\
\hline TQ-20 & V & III & IV & IV & III & I & I & II \\
\hline APP-22 & III & $\mathrm{V}$ & IV & - & - & I & I & III \\
\hline PB1-23 & - & $\mathrm{V}$ & $\mathrm{V}$ & - & - & - & - & - \\
\hline PB2-23 & - & - & - & - & - & - & - & III \\
\hline CLB-33 & - & $\mathrm{V}$ & V & - & - & - & III & $\mathrm{V}$ \\
\hline DAS-36 & V & V & IV & II & II & II & II & IV \\
\hline DGM-36 & $\mathrm{V}$ & $\mathrm{V}$ & V & - & IV & $\mathrm{V}$ & - & V \\
\hline PC-36 & IV & II & IV & II & III & III & II & I \\
\hline TC-36 & - & - & - & I & IV & I & III & - \\
\hline TP-36 & V & $\mathrm{V}$ & IV & - & IV & I & II & II \\
\hline CPCh-37 & $\mathrm{V}$ & IV & III & I & I & I & - & I \\
\hline C1836-43 & IV & $\mathrm{V}$ & II & - & - & - & III & V \\
\hline CCX-46 & III & III & III & - & II & - & III & $\mathrm{V}$ \\
\hline
\end{tabular}

Táboa 12. Cotexo dos textos anónimos editados en Papés

Somos conscientes da necesidade de ampliar o estudo coa análise de moitos máis trazos antes de tirar conclusións suficientemente apoiadas. Ora ben, por continuar coa exposición do método seguido, parece que os trazos analizados comproban, por exemplo, a gran similitude entre DAS-36 e TP-36, o que non desmente a hipótese lanzada de maneira reiterada de que poidan ser da mesma man, da que se fai eco Couceiro Freijomil, xunto co rumor da posible autoría: "Se le atribuyen [a Vicente Turnes del Río Maldonado] los periódicos redactados en gallego Dialogos en la Alameda de Santiago y su continuación La Tertulia de 
Picaños, que salían irregularmente" (1953: 423-424). Os nosos datos tampouco desmenten esa posible atribución: Turnes usa sempre non ante verbo comezado por vogal (grupo V); ante pronome acusativo emprega as dúas opcións (Grupo III) — fronte á constancia de non dos textos anónimos—, mais con só dous rexistros, un de cada forma; no uso de lles móvese en proporcións semellantes (VT: 69,23\%; DAS: 77,78\%; TP: 81,25\%); non hai datos do uso de llelo e variantes, a falta de contextos adecuados; coincide con DAS na concorrencia de ninguén con nadia (1), da que se desvía TP (nadie, 1); tamén coinciden Turnes e DAS na alternancia entre nós e nosoutros, en proporcións semellantes (respectivamente, $71,43 \%$ e $88,89 \%$ de formas simples); non é unha diferenza a ter en conta o feito de que o único rexistro de formas de tratamento en Turnes sexa de vós (Grupo I) e que en DAS e TP haxa variación entre as dúas opcións (Grupo II); coincide tamén con DAS e TP na concorrencia de $\{a c a ́, a c o ́\}$ e $\{a l a ́, a l o ́\}$, ben que os tres en proporcións desemellantes (-ál-ó: VT 4/ 4, DAS 1/11, TP 3/1).

Podería concluírse que, con algunha distancia, tamén TQ-20 se asemella moito a DAS-36 e TP-36, ao fin e ao cabo todos producidos en ambiente compostelán, e con só estes datos non poderiamos dicir afirmar nin negar con seguridade que son do mesmo autor. Pero non ocorre o mesmo con DDF-20, editado na mesma cidade, que mostra unha práctica lingüística moi diverxente e para o que se ten proposto a mesma autoría ca CR-12 (Papés: 147). Se cotexamos os resultados da análise da variación en ámbolos textos, debemos concluír que non hai base para a identificación como obras dun mesmo autor: coinciden só no uso de non ante verbo comezado por vogal, na concorrencia de nós e nosoutros (uso da forma simple: CR-12 46,15\%, DDF 50,00\%) e na selección de adverbios en -á; difiren, situándose como contrarios nos dous extremos do arco, no uso de variantes reducidas do adv. non ante acusativo e da forma do dativo; non hai datos dos outros trazos considerados.

Investigacións recentes doutro teor permitiron establecer que RM-44, asinado coas siglas J. P. V., é da autoría de Ramón Malvárez, párroco de Miñortos (Noia), que algúns postulan como autor tamén de CPCH-37. Apenas temos datos para apoiar ou contradicir esta hipótese, pois o texto de atribución segura só nos dá datos de catro dos fenómenos considerados: en tres deles móstranse coincidentes (ninguén, nós e alá) e noutro a dixerxencia é máxima (RM-44: n' ante vogal [3r]). En cambio, si podemos afirmar que non hai unha base 
segura para atribuír CPCh-37 ao mesmo autor ca DAS-36 e TP-36, como fora suxerido (cf. Carvalho 1984), pois mostran unha práctica lingüística ben diferenciada.

Rematamos esta mostra co cotexo de DE-07 coa dos outros autores que os editores poñen en conexión con este diálogo: dunha banda, Fandiño, que segundo afirman nolos transmite coa súa letra (Papés: 27); doutra Freire Castrillón, que postulan como un autor verosímil pola súa desmesura, razón pola que xulgan tamén pode ser autor de AC-13 (Papés: 153; a falta dun texto de autoría segura, tomaremos este como referencia). Os datos considerados non apoian a intervención autoral de Fandiño, que prefire formas abreviadas de non ante verbo comezado por vogal, alterna as plenas e as reducidas ante acusativo e sempre usa lles, nosoutros e alá; dito doutro xeito, dos seis trazos que podemos confrontar entre ambos, Fandiño e o autor de DE-07 só coinciden na preferencia por ninguén. Máis problemática é a comparación con AC-13, con moi pouca base, porque só nos permite contrastar dous trazos; ora ben, neles non hai coincidencia plena, xa que en AC-13 sempre usa non ante vogal e os pronomes nós, vós en forma reducida. Noutro lugar, combinando dez trazos de vario tipo, entre os que non se atopaba ningún dos analizados nesta contribución, chegamos á conclusión de que non hai base lingüística para identificar o autor de DE-07 con ningún dos autores propostos e sinalamos, por contra, a maior similitude con algúns dos diálogos producidos nos círculos liberais composteláns, que hoxe reiteramos (Álvarez 2008). Así pois, é nese ambiente onde cómpre buscar a persoa que tiña a ocasión e cumpría o resto das características.

En definitiva, ante a pregunta formulada no título somos moderadamente optimistas. Confiamos en que os obxectivos propostos se acaden tras un estudo rigoroso da variación lingüística nestes autores e nestas obras, que teña en conta non só a presenza/ausencia senón tamén a incidencia das distintas variantes, e ademais atenda aos posibles procesos de cambio lingüístico que estaban en curso ao longo do período. Sobre esas bases, poderemos lanzar hipóteses mellor fundamentadas sobre os perfís lingüísticos dos autores anónimos e, asemade, avalar ou desbotar posibles identificacións. Esta é unha tarefa importante para a historia da lingua e a literatura galegas, que debe recuperar para a memoria os nomes dos seus protagonistas. É tamén o cumprimento dunha obriga comunitaria, como parte da débeda que todos temos contraída con eles. 


\section{BibLiografía}

ALGa = García, Constantino et alii (1995): Atlas Lingüistico Galego. Volume II: Morfoloxía non verbal. A Coruña: Instituto da Lingua Galega / Fundación Pedro Barrié de la Maza.

Álvarez Blanco, Rosario (1980): O pronome persoal en galego. Tese de doutoramento. 2 vols. Universidade de Santiago de Compostela.

Álvarez, Rosario (1994): "Unha ollada moderna sobre a lingua dos nosos devanceiros", in Estudios galegos en homenaxe ó Profesor Giuseppe Tavani, Santiago de Compostela: CILL Ramón Piñeiro, 153-167.

Álvarez, Rosario (1996): "As formas de dativo e a expresión do número en galego medieval: lle/lles, llo/ llelo", Verba 21, 133-166.

Álvarez, Rosario (1998): O pronome persoal. Morfoloxía e variación dialectal. Traballo orixinal de investigación, concurso de acceso ao corpo de CAT-UN. Universidade de Santiago de Compostela.

Álvarez, Rosario (2008): «Denuncia pública e autor anónimo. O Diálogo dos esterqueiros (1807)», en X. L. Axeitos / E. Grandío Seoane / R. Villares (eds.): A patria enteira. Homenaxe a Xosé Ramón Barreiro Fernández. Santiago de Compostela: CCG / RAG / USC, 953-972.

Álvarez, Rosario (2010): "As razóns da norma: nós e nosoutros, nosoutras", Estudos de Lingüistica Galega 2, 205-220 [DOI 10.3309/1989-578X-10-10].

Álvarez, Rosario / Xosé Luís Rodríguez Montederramo (2006): «Un prego solto en galego en defensa do liberalismo: «A parola poléteca», de 1822», Boletín da Real Academia Galega 367, 2006, 141-193.

Álvarez, Rosario / Xosé Xove (2002): Gramática da lingua galega. Vigo: Galaxia.

Álvarez, Rosario / Xosé Xove (2008a): «Os adverbios alálaló, acál acó. Unha perspectiva dialectal», en M.

Brea / F. Fernández Rei / X. L. Regueira (eds.) (2008): Cada palabra pesaba, cada palabra medía. Homenaxe a Antón Santamarina. Santiago de Compostela: USC, 193-224.

Álvarez, Rosario / Xosé Xove (2008b): «Os adverbios alálaló, acál acó en galego medieval», en E. Corral Díaz / L. Fontoira Surís / E. Moscoso Mato (eds.): «A mi dizen quantos amigos ey». Homenaxe ao profesor Xosé Luís Couceiro, Santiago de Compostela: USC, 377-403.

Carballo Calero, Ricardo (1975): Historia da literatura galega contemporánea. Vigo: Galaxia.

Carballo Calero, Ricardo (1983): "Diálogos gallegos de tradición renacentista (1810-1837)”, 1616: Anuario de la Sociedad Española de Literatura General y Comparada 5, 13-21.

Carvalho Calero, Ricardo (1984): "Conjecturas sobre a autoría dos diálogos compostelanos de princípios do século XIX (1812-1836)”, en Actas. I Congresso internacional da língua galego-portuguesa na Galiza. Ourense: AGAL.

Cintra, Luís F. L. (1972): Sobre "Formas de Tratamento" na Lingua Portuguesa. Lisboa: Livros Horizonte.

Dubert García, Francisco (1999): Aspectos do galego de Santiago de Compostela. Santiago de Compostela: USC.

Iglesia, Antonio de LA (1861): "El poeta gallego D. Vicente de Turnes", Galicia: revista universal de este reino 11, 1-III-1861, 169-170.

Lapesa Melgar, Rafael (1970): “Personas gramaticales y tratamientos en español”, en Homenaje a Menéndez Pidal, IV. Separata de Revista de la Universidad de Madrid 19, 141-167.

Mariño Paz, Ramón (2003): O idioma galego no limiar da súa renacenza. Estudo lingüístico de textos pregaleguistas. Anexo de Revista Galega de Filoloxía, A Coruña, Área de Filoloxías Galega e Portuguesa, Departamento de Galego-Portugués, Francés e Lingüística. 
Mariño Paz, Ramón / X. R. Barreiro Fernández / Rosa Aneiros Díaz (eds.) (2008): Papés d'emprenta condenada. A escrita Galega entre 1797 e 1846 (I). Santiago de Compostela: Consello da Cultura Galega. Monteagudo, Henrique (2008): Letras primeiras. O Foral do Burgo de Caldelas, a emerxencia da escrita en galego e os primordios da lírica trobadoresca. A Coruña: Fundación Pedro Barrié de la Maza / Instituto da Lingua Galega.

Pérez Constanti, Pablo ([1911-14] 1998): Linajes galicianos. Santiago de Compostela: Ara Solis / Consorcio de Santiago.

Saco Arce, Juan A. (19868): Gramática gallega. Lugo: Imprenta de Soto Freire.

TMILG = Varela Barreiro, Francisco Xavier (dir.): Tesouro medieval informatizado da lingua galega. Santiago de Compostela: Instituto da Lingua Galega. http://ilg.usc.es/tmilg/ [set.-nov. 2009].

Valladares NúNez, Marcial (1970 [1892]): Elementos de gramática gallega. Vigo: Galaxia.

Xove, Xosé (1999): “O primeiro texto galego coñecido de Juan Manuel Pintos”, en X. L. Couceiro et alii (coords.): Homenaxe ó profesor Camilo Flores. Santiago de Compostela: USC, II, 731-740. 